\title{
Neolithic land use in the northern Boreal zone: high-resolution multiproxy analyses from Lake Huhdasjärvi, south-eastern Finland
}

\author{
Teija Alenius $^{1,4}\left(\right.$ D $\cdot$ Teemu Mökkönen ${ }^{2} \cdot$ Elisabeth Holmqvist $^{1} \cdot$ Antti Ojala $^{3}$
}

Received: 30 September 2016 / Accepted: 3 February 2017 / Published online: 14 March 2017

(C) The Author(s) 2017. This article is published with open access at Springerlink.com

\begin{abstract}
Two high-resolution pollen and charcoal analyses were constructed from sediments obtained from a small bay in eastern Finland in order to gain information on human activity during the Neolithic Stone Age, 5200-1800 BC. We used measurements of loss on ignition (LOI), magnetic susceptibility and geochemical analyses to describe the sedimentological characteristics. Palaeomagnetic dating and measurements of ${ }^{137} \mathrm{Cs}$-activity were supported by ${ }^{14} \mathrm{C}$-datings. The analyses revealed human activity between 4400 and $3200 \mathrm{BC}$, which is synchronous with archaeological cultures defined through different stages of Comb Ware pottery types and Middle Neolithic pottery types with asbestos as a primary temper. Direct evidence of Hordeum cultivation was dated to 4040-3930 cal вс. According to the pollen data, more significant effort was put into the production of fibres from hemp and lime than the actual cultivation of food.
\end{abstract}

Keywords Pollen analysis · South-eastern Finland · Land use $\cdot$ Neolithic $\cdot$ Lake sediments · Geochemistry

Communicated by M.-J. Gaillard.

Teija Alenius

teija.alenius@helsinki.fi

1 Department of Philosophy, History, Culture and Art Studies, University of Helsinki, Unioninkatu 38 F, P.O.Box 59, 00014 Helsinki, Finland

2 Department of Archaeology, University of Oulu, Oulu, Finland

3 Geological Survey of Finland, Espoo, Finland

4 Department of Archaeology, University of Turku, Turku, Finland

\section{Introduction}

In eastern Fennoscandia (Finland and the Republic of Karelia, Russia), the Neolithic period begins with the appearance of pottery ca. 5300-5200 BC (Pesonen et al. 2012; Nordqvist and Mökkönen 2016). In the Baltic States, this took place a few decades earlier (Piezonka 2012). According to the traditional interpretation, in eastern Fennoscandia and in the Baltic States, the beginning of the Neolithic period was not associated with agriculture. Traditionally, the earliest agriculture in much of northern Europe has been associated with the much later Corded Ware phenomenon, which spread from central Europe to eastern Fennoscandia in the early third millennium вс (e.g. Carpelan 1999; Zvelebil and Lillie 2000). High-resolution pollen analyses obtained from southern and eastern Finland (Alenius et al. 2013; Augustsson et al. 2013), western Russia (Königsson et al. 1997; Vuorela et al. 2001) and Estonia (Kriiska 2003; Poska et al. 2004; Poska and Saarse 2006), as well as archaeological data from the same area (Kriiska 2009; Nordqvist and Kriiska 2015), have challenged the traditional interpretation of northern European prehistory. There is increasing evidence that the initial stage of cereal cultivation in northern Europe took place at the very beginning of the Neolithic Stone Age, ca. 5200-4000 BC, concurrent with the appearance of pottery in eastern Fennoscandia. On the basis of circumstantial evidence, it has been proposed that eastern pottery technology and early cultivation spread concurrently into the north-eastern part of the Baltic Sea through the same networks (Mökkönen 2010, 2011), but until recently, no data were available to actually demonstrate the connection in Finland.

In south-eastern Finland, the evidence from highresolution pollen analysis indicates Stone Age cultivation around Lake Huhdasjärvi, where pollen originating 
from Fagopyrum esculentum has been dated to the transition period between the Mesolithic and Neolithic periods, $5370-5060 \mathrm{cal}$ вс (28). This was then followed by Hordeum pollen dated to ca. 4260 BC and 2160 BC (Alenius et al. 2013). In Estonia, some pollen evidence shows cultivation during the fifth millennium BC (Kriiska 2009). In addition, several older, less accurate pollen analyses point to disturbances in vegetation and the sporadic presence of Cerealia-type pollen from the fifth millennium cal $\mathrm{BC}$ onwards in the area south of the Arctic Circle in Finland (Reynaud and Hjelmroos 1980).

In a wider perspective, more evidence of cultivation and anthropogenic disturbances in vegetation appears around 4000 BC when Typical Comb Ware spread extensively to the eastern part of the Baltic Sea (Kriiska 2009; Mökkönen 2010; Nordqvist and Kriiska 2015). In Estonia, abundant and continuous pollen evidence for different cereals starts around 4000 вс (Kriiska 2009). In Lake Onega, Russia, signs of cereal cultivation dating to ca. 3800 BC have been encountered (Vuorela et al. 2001). In Lake Ahvenainen, southern Finland, Cerealia (possibly Triticum-type pollen) was dated to ca. 3400-3350 вс and Hordeum-type to ca. 2700-2680 BC (Tolonen 1978). In the pollen data obtained from Lake Lehmilampi in eastern Finland, the first possible indications of human impact, including one Hordeum-type, were observed between 3000 and 2500 BC (Augustsson et al. 2013).

Typical Comb Ware (3900-3500 BC), which roughly covers the area of Finland, Estonia, northern Latvia and parts of north-western Russia, represents a pottery tradition originating in the upper Volga region. In addition to increasing signs of cultivation, the appearance of this new pottery style around 3900 BC is marked by new contact networks that are in some regions explained through small-scale migration and in other areas through cultural diffusion, the movement of new ideas and material goods (Nordqvist and Kriiska 2015; Nordqvist et al. 2015). At that time, other exotic materials - flint from the east (Vuorinen 1982; Kinnunen et al. 1985; Mökkönen and Nordqvist 2016), amber from the southern Baltic region (Vuorinen 1984; Núñez and Franzen 2011), rock crystals from southern to south-eastern Finland (Mökkönen and Nordqvist 2016) and copper from the Lake Onega region, Russia (Taavitsainen 1982; Nordqvist and Herva 2013) were more intensively used as novel raw materials. Rock art flourished (Lahelma 2008; Gjerde 2010), and semi-subterranean pithouses that often occur in villagelike concentrations became the dominant dwelling type (Pesonen 2002; Vaneeckhout 2009; Mökkönen 2011). At the same time, there arose a new awareness that included a range of new techniques for manipulating materials and engaging with the material world. As a whole, these are seen as integral elements of Neolithization in north-eastern Europe and Eurasia (Nordqvist and Herva 2013; Herva et al. 2014, 2017; Nordqvist et al. 2014, 2015; Nordqvist and Kriiska 2015). Although traditional elements of the material culture that defines the Neolithic Stone Age have been known to be present among north-eastern European cultures, which were previously labelled as Subneolithic or even as pottery Mesolithic cultures (e.g. Werbart 1998; Davidson et al. 2009), the new insights concerning changes in the engagement with the material world have enriched the nature of the Neolithization process and thus also altered the context to which the record of early cultivation is considered to belong.

Still, the archaeobotanical record is far from sufficient for understanding the role of cultivation during the Neolithic in north-eastern Europe. In order to capture the earliest, often very slight anthropogenic signals and to understand the role of cultivation, it is necessary to produce accurate and high-resolution pollen data from lake sediments. In this study, we take a closer look at a small body of water, Lake Huhdasjärvi, located within the limits of the modern town of Kouvola in the northern part of the province of Kymenlaakso, beyond the 60th

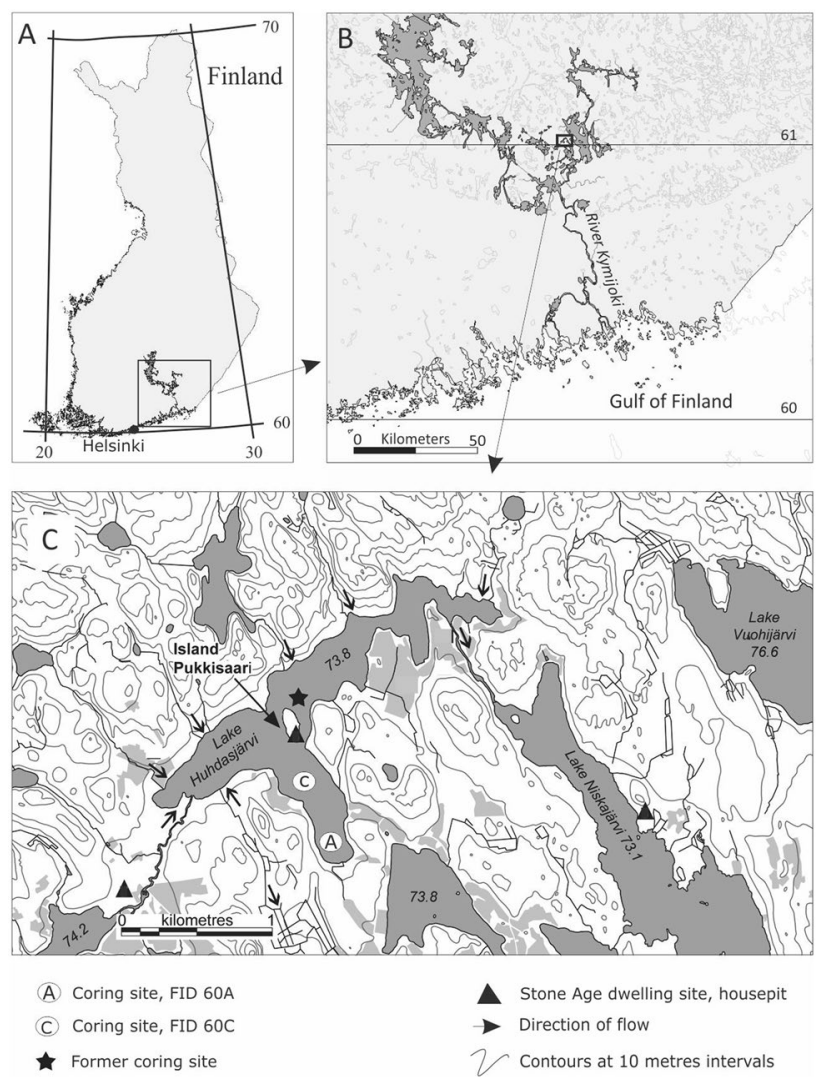

Fig. 1 a Location of the study area in south-eastern Finland. b Drainage basin of the Kymijoki river. c Lake Huhdasjärvi coring sites and Stone Age dwelling sites 
parallel north in Finland (Fig. 1). This is a Y-shaped lake that has evidenced small-scale cultivation of Fagopyrum esculentum (buckwheat), Cannabis (hemp) and Hordeum (barley) during the early phase of the Neolithic, ca. 5300-3600 cal BC (Alenius et al. 2013). Two locations in the bay of Pitkälahti were selected for high resolution pollen analyses in order to find out more detailed information on the Neolithic cultivation and land use phase detected in an earlier analysis (Alenius et al. 2013). The presence of distinctively eastern species, i.e. buckwheat and hemp, dating to the beginning of the Neolithic is not profoundly surprising, as the earliest pottery traditions in north-eastern Europe also originate from the Asian tradition (e.g. Jordan and Zvelebil 2010). Therefore, it has been proposed that the spread of eastern pottery traditions in the boreal forest zone was actually accompanied by some initial small-scale cultivation since the very beginning (Alenius et al. 2013; see also; Mökkönen 2010). In general, scenarios of the journey of eastern plants to Europe during the Stone Age have been proposed before, but the time frames of the movement are still rather unclear (e.g. Janik 2002; Jones et al. 2011; Boivin et al. 2012; Gepts et al. 2012).

\section{Study area and site description}

\section{Environmental setting}

Lake Huhdasjärvi (61.17109 N; $26.59148 \mathrm{E}$ in WGS84 coordinates) is located in the province of Kymenlaakso in south-eastern Finland, approximately $140 \mathrm{~km}$ north-east of the capital, Helsinki (Fig. 1a, b). The lake belongs to the drainage basin of the Kymijoki river and is situated at an altitude of $73.8 \mathrm{~m}$ a.s.l. Judging by its present altitude and the rate of land uplift, which is ca. $7 \mathrm{~mm}$ per year (Saarnisto 1970), the lake emerged from the Baltic Sea during the Early Holocene, or around 8500 BC. At present, the lake is Y-shaped and each arm has a radius of about $1.5 \mathrm{~km}$ (Fig. 1c). The lake is fed by one small river and several small brooks, and it has one outlet.

The area belongs to the Southern Boreal zone, where the length of the growing season is 160-175 days. The vegetation is characterized by coniferous forests of Picea abies (spruce) and Pinus sylvestris (pine) and deciduous trees, namely Betula pendula and B. pubescens (birches), Populus tremula (aspen), Alnus incana and A. glutinosa (alders) (Alalammi 1988). Today, the mean annual precipitation is $550 \mathrm{~mm}$, of which about $200 \mathrm{~mm}$ is received as snow. The mean annual temperature is +3.5 to $+4{ }^{\circ} \mathrm{C}$, the warmest month being July $\left(+17^{\circ} \mathrm{C}\right)$ and the coldest January and February (between -9 and $-8^{\circ} \mathrm{C}$ ) (Alalammi 1987). The dominating relief amplitude is of the order of $30-75 \mathrm{~m}$. The dominating soil type around Lake Huhdasjärvi is moraine, although there are also large areas of exposed bedrock. The narrow stripes of former grove vegetation on the shores of the lake have currently more or less been transformed into agricultural land.

\section{Archaeological context}

An archaeological survey of the area was conducted in connection with the earlier studies (Alenius et al. 2013). Despite the thorough survey, the total number of Stone Age sites found within a radius of ca. $10 \mathrm{~km}$ around Lake Huhdasjärvi is rather small, altogether 25 sites. Most of the dwelling sites are small in size, and they are characterized by infrequent finds, such as quartz flakes and fragments of burnt bones, that could not be dated on their own. The total number of sites includes five locations with rock paintings (see Alenius et al. 2013).

There are no structures visible on the surface at 12 of the Stone Age sites. Permanent dwelling structures, namely the bases of semi-subterranean pithouses, are recorded at eight sites, and they occur alone or in pairs. The housepit sites, with the exception of two sites - the one located in the Lake Huhdasjärvi area and another one by a small lake nearby-are located on the shores of larger lakes and waterways (Alenius et al. 2013). The shape of the housepits varies from round to oblong or rectangular and the size varies between 20 and $60 \mathrm{~m}^{2}$. In Finland, housepits are increasingly found in archaeological data from around 4000 BC (Pesonen 2002; Mökkönen 2011). The smaller roundish housepits are most typical for the period between ca. 4000 and $3400 \mathrm{BC}$, even though they continue to occur in small numbers until the end of the Stone Age, while the rectangular and more oblong housepits, which are often larger in size and deeper, date distinctly to the latter part of the Stone Age, starting from ca. 3500 BC (Mökkönen 2002, 2011). Four of the housepits in the area definitely belong to the latter group.

There are only three Neolithic sites with pottery shards that could be identified as a certain type. One is located on the island of Pukkisaari in the middle of Lake Huhdasjärvi, just next to locations where the current and previous samples for pollen analysis were cored. One of the two pithouse bases at the Pukkisaari site is partly excavated; in addition to quartz debris, the finds included pottery (an organictempered variant of Pöljä Ware), two grindstone slabs, an amber button, and three small scrapers made of slate (Miettinen 1998, 2004, 2012). Based on radiocarbon dates, the site is dated to ca. 3020-2630 cal BC (Alenius et al. 2013). The second site with identified pottery is the Nuumanniemi site, which is located slightly less than $10 \mathrm{~km}$ from Lake Huhdasjärvi, with shards of Early Comb Ware of the I:2 style (Miettinen 2004). This pottery style is dated to ca. 
4500-4200 BC (Pesonen et al. 2012; Nordqvist and Mökkönen 2016). In addition, a housepit site called Hintteri has produced a few pieces of asbestos-tempered pottery that can be dated roughly to $3500-2500 \mathrm{cal}$ BC.

To sum up, the archaeological finds indicating Stone Age habitation are modest, and most of the sites could not be dated more accurately than to the Stone Age or to the subsequent Early Metal Period (in the inland areas of Finland, this is dated to 1800 BC-AD 300). In general, during most of the Neolithic Stone Age, the area could be described as a periphery - an area that was only passed through or occupied on a limited scale. The Nuumanniemi site with Early Comb Ware of the style I:2 is the only datable site older than ca. 3500 BC. Radiocarbon dates, detected pottery (even small amounts), and certain housepit types indicate more active habitation in the area during the latter part of the Neolithic, after $3500 \mathrm{BC}$, although this picture could be at least partly an illusion created by the unequal archaeological visibility of different periods.

\section{Materials and methods}

\section{Coring, sediment stratigraphy and geochemistry}

Sedimentological methods used in this work include measurements of loss on ignition (LOI), magnetic susceptibility, geochemical analyses, palaeomagnetic dating and measurements of ${ }^{137} \mathrm{Cs}$-activity. The sediment samples were cored standing on the frozen surface of the lake in February 2014, using a light, rod-operated piston corer (Putkinen and Saarelainen 1998). Sediment samples were taken from two different locations in Lake Huhdasjärvi. The first set (FID 60 A) was taken from the end of the Pitkälahti bay (61.1626833 N; 26.59653162 E in WGS84), where the water depth was $9.40 \mathrm{~m}$. The second core (FID $60 \mathrm{C}$ ) was taken from the middle of the Pitkälahti bay (61.16581451 N; 26.59327747 $\mathrm{E}$ in WGS84), where the water depth was $12.70 \mathrm{~m}$ (Fig. 1c).

From the end of the Pitkälahti bay (FID 60 A), we retrieved two parallel sets of cores. Both sets of cores consist of two overlapping sediment sequences: core 1a $(0-198 \mathrm{~cm})$ and core $1 \mathrm{~b}(160-360 \mathrm{~cm})$, and core $2 \mathrm{a}$ $(0-195 \mathrm{~cm})$ and core $2 \mathrm{~b}(160-360 \mathrm{~cm})$. From the middle of the Pitkälahti bay, one set of sediment sequences, FID $60 \mathrm{C}$, was obtained: cores $1 \mathrm{a}(0-201)$ and $1 \mathrm{~b}(160-360 \mathrm{~cm})$. The correlation of the three sets of sub cores was verified by LOI, measurements of magnetic susceptibility, and visual sediment stratigraphy.

LOI was determined at $1-\mathrm{cm}$ resolution by burning previously dried $\left(105^{\circ} \mathrm{C}\right.$, overnight) sediment samples in a furnace for $2 \mathrm{~h}$ at $550^{\circ} \mathrm{C}$. Volume magnetic susceptibility (к) was determined at $5 \mathrm{~mm}$ intervals using a Bartington MS2E1 surface-scanning sensor.

The core 1a and core $1 \mathrm{~b}$ samples, which were obtained from the end of the Pitkälahti bay, were analysed using a portable energy-dispersive X-ray fluorescence spectrometer (pXRF) in order to detect chemical signals in the sediment sequence possibly linked to anthropogenic activities in the catchment area (e.g. Wilson et al. 2008). PXRF analysis of unprepared sediment samples can generate semi-quantitative concentration values of high- $Z$ elements applicable for the chemical discrimination of different sediment layers. However, values in the low/mid-Z range should be treated with caution given the analytical limitations of this instrumentation, mainly the lack of vacuum and suitable calibration (Davis et al. 2012; Hunt and Speakman 2015; Holmqvist 2017). In particular, accuracy issues affect the elements $\mathrm{Na}, \mathrm{P}, \mathrm{V}, \mathrm{Cr}$ and $\mathrm{Ni}$, which cannot be accurately quantified (Hunt and Speakman 2015). However, of these elements, $\mathrm{P}$ was included our analysis, as it was detected at several sediment depths.

The instrument employed was a portable hand-held Bruker S1 Titan energy-dispersive X-ray fluorescence spectrometer equipped with a silicon drift detector (SDD), available at the University of Helsinki. The instrument has an Rh-target X-ray tube, and it was operated using the Geochem calibration mode provided by the manufacturer (voltage $45 \mathrm{kV}$, current $8.9 \mu \mathrm{A}$ with TiAl filter for the heavy element detection and $15 \mathrm{kV} / 30 \mu \mathrm{A}$ with no filter for light element analysis). Each centimetre of the core sample was analysed individually (acquisition time $120 \mathrm{~s}$ per sample) after the samples were dried and burned for the LOI determination to exclude any interference from organic materials or moisture. In order to examine the sedimentary geochemistry, the elements $\mathrm{P}, \mathrm{S}, \mathrm{Cl}, \mathrm{K}, \mathrm{Ca}, \mathrm{Ti}, \mathrm{Mn}, \mathrm{Fe}, \mathrm{Zn}, \mathrm{Rb}$, $\mathrm{Sr}, \mathrm{Y}$ and $\mathrm{Zr}$ were selected for the final analysis. The instrument software was used to quantify the fluorescence peaks to concentration values, treated as semi-quantitative markers of the sediment geochemistry in our analysis.

\section{Dating}

Dating of the Lake Huhdasjärvi sediment sequences is based on a combination of palaeomagnetic dating (e.g. Thompson and Oldfield 1986; King and Peck 2001), radiocarbon dating (AMS ${ }^{14} \mathrm{C}$ ) and analysis of anthropogenic ${ }^{137}$ Cs-activity of the recently deposited sediments. Cs measurements were conducted at a resolution of $1 \mathrm{~cm}$ at the Geological Survey of Finland (GSF) using a gamma spectrometer EG\&G Ortec $\mathrm{ACE}^{\mathrm{TM}}-2 \mathrm{~K}$ equipped with a fourinch $\mathrm{NaI} / \mathrm{TI}$ detector.

Sediment sampling for palaeomagnetic measurements and testing of the stability of natural remanent magnetization (NRM) followed Ojala and Tiljander (2003), and 
the palaeosecular variation (PSV) results from the Lake Huhdasjärvi sequence were compared with the FENNOSTACK (Snowball et al. 2007) Lake Nautajärvi (Ojala and Tiljander 2003) varve-dated reference curves. These reference curves are based on carefully documented sedimentary varve chronology with an estimated error of less than $\pm 1 \%$. Palaeomagnetic measurements were made at GSF with a 2G-Enterprises SRM-755R tri-axial SQUID magnetometer and the PSV inclination and declination curves were matched with the reference curves to construct an age-depth transformation for the Lake Huhdasjärvi sediment sequence.

The result of the palaeomagnetic dating was supported by three radiocarbon analyses from sediment depth levels 175,206 , and $210 \mathrm{~cm}$ to specify certain points in the time-depth curve for the core location FID 60 A (Table 1). In addition, with both sequences, the age-depth chronology was anchored to the rise of Picea pollen grains in the sediment sequences, which were radiocarbon-dated in the previous study by Alenius et al. (2013), and Tilia pollen grains, which were radiocarbon-dated earlier by Tolonen and Ruuhijärvi (1976). We used a Bayesian P-sequence deposition model in Oxcal 4.2 software by Bronk Ramsey $(2008,2009)$ to calibrate the radiocarbon dates and to fit PSV characteristics to the age-depth model in order to provide a sediment chronology for the Lake Huhdasjärvi sediment sequence. Henceforth, we use the prefix "cal" with вС dates when referring to a specific calibrated ${ }^{14} \mathrm{C}$ sample, but the prefix "cal" is omitted when referring to the interpolated age-depth model or archaeological periods.

\section{Pollen and charcoal analysis}

For calculations of pollen and charcoal concentrations (number of pollen grains or charcoal particles per $\mathrm{cm}^{3}$ of sediment), two Lycopodium tablets (Stockmarr 1971) were added to samples of $1 \mathrm{~cm}^{3}$ in volume. Subsamples for pollen analysis were prepared according to the procedure suggested by Bennett and Willis (2001). No acetolysis treatment was used. Glycerol was used as a mounting medium. In order to obtain a high temporal resolution, all the sediment samples were analysed in each $\mathrm{cm}$ from the part of the sediment that covers the range between ca. 6000 and 1000 вс.
A minimum of 900 pollen grains per sample were identified using publications of Erdtman et al. (1961), Fægri and Iversen (1989), Moore et al. (1991), Reille (1992, 1995) and Beug (2004). Microcharcoal fragments $>10 \mu \mathrm{m}$ were counted on the pollen slides. Different authors have different size criteria for the limit of Humulus/Cannabis-types. In the identification key by Fægri and Iversen (1989), all the Humulus/Cannabis-types larger than $20 \mu \mathrm{m}$ are identified as Cannabis. Erdtman et al. (1961) use a size limit of $22.5 \mu \mathrm{m}$. According to Beug (2004), the mean value for Humulus lupulus is $23.4 \mu \mathrm{m}$, and for Cannabis sativa $28.1 \mu \mathrm{m}$, in pollen samples that are treated with acetolysis and mounted in glycerin-gelatine. In order to avoid the classification of Humulus-type pollen into Cannabis, all the Humulus/Cannabis-types of pollen grains $\geq 30 \mu \mathrm{m}$ were determined as Cannabis sativa. Cereal pollen identification was based on the following criteria: grains between 40 and $60 \mu \mathrm{m}$ with an annulus diameter $>10 \mu \mathrm{m}$ and a distinct outer margin were identified as cereals and distinct from the wild grass group. Secale was distinguished from other cereal pollen by its oblong outline, scabrate surface, and the undulating outer margin of its annulus. Hordeum was identified based on its annulus diameter of 10-12 $\mu \mathrm{m}$, while grains with an annulus diameter larger than $12 \mu \mathrm{m}$ were assigned to the Avena-Triticum group.

Calculations for pollen percentages were based on the basic sum of terrestrial pollen grains, $\mathrm{P}$, that includes arboreal pollen $[\mathrm{AP}=$ including Picea, Pinus, Betula, Alnus $]$, non-arboreal pollen (NAP), and noble deciduous trees [=QM including Corylus (hazel), Ulmus (elm), Quercus (oak), Tilia (lime), Carpinus (hornbeam), Fraxinus (ash) and Fagus (beech)]. The aquatic pollen and spores were calculated from the sums $\mathrm{P}+\mathrm{AqP}$ and $\mathrm{P}+$ Spores.

Biostratigraphical data treatment and diagrams were handled with Grimm's (1991) TILIA and TILIA GRAPH programs. Constrained Incremental Sum of Squares (CONISS) (Grimm 1987) was used to assist zonation. We used stratigraphically constrained analysis and square root transformation. In order to avoid the dominance of main tree species, which would likely illustrate regional forest development history, only pollen taxa originating from herbs were included in the analysis. To estimate palynological richness, rarefaction analysis (Birks and Line 1992) was carried out using the POLPAL program (Walanus and

Table 1 Radiocarbon dates of the Huhdasjärvi sediment sequence obtained from core FID 60 A. The calibration was made with the OxCal 4.2 software (Bronk Ramsey 2009), which employs the Intcal09 calibration curve (Reimer et al. 2009)

\begin{tabular}{llllll}
\hline Lab. code & Depth $(\mathrm{cm})$ & ${ }^{14}$ C age year вP & cal age $(1 \sigma)$ & cal age $(2 \sigma)$ & Median \\
\hline Poz-79,592 & 175 & $4,330 \pm 35$ & $2942-2898$ вС $(41.1 \%)$ & $3024-2890$ вС $(94.8 \%)$ & 2950 вС \\
Poz-79,593 & 206 & $5,195 \pm 35$ & $4001-3968$ вС $(40.4 \%)$ & $4055-3951$ вС $(94.6 \%)$ \\
Poz-79,594 & 210 & $5,150 \pm 35$ & $3995-943$ вС $(57.9 \%)$ & $4041-3932$ вС $(76.0 \%)$ & 4001 вС \\
\hline
\end{tabular}


Nalepka 1999). In both cores, the sum for rarefaction analysis was set to 600 .

\section{Results}

\section{Sediment description, chronology and geochemistry}

Sediment stratigraphy, LOI and magnetic susceptibility indicated that cores FID $60 \mathrm{~A}$ and FID $60 \mathrm{C}$ and their overlapping sequences contained similar sedimentary data and provided a solid basis for their correlation (Fig. 2). The sediment deposits consist of homogeneous fine-detritus gyttja with only a few weakly laminated sections down to a sediment depth of about $250 \mathrm{~cm}$. Below that lies faintly laminated clay gyttja (partly gyttja) that gradually shifts to sulphide-bearing gyttja clay at a depth of $350 \mathrm{~cm}$.

The sedimentary signal of chemical components is rather flat throughout the sequence, excluding the lowermost part of the sediment (below $260 \mathrm{~cm}$ ) and the uppermost ca. $27 \mathrm{~cm}$ (about $1500 \mathrm{cal} \mathrm{AD}$ ), where Rb, Sr and $\mathrm{Zr}$ increase rapidly (Fig. 2). Fe, $\mathrm{Zn}$ and $\mathrm{Y}$ first decrease and then increase in the topmost $5 \mathrm{~cm}$. However, small fluctuations can be seen throughout the sediment core in the values of $\mathrm{Fe}, \mathrm{Rb}, \mathrm{Zn}, \mathrm{Sr}, \mathrm{Y}$ and $\mathrm{Zr}$, although the absolute differences between the measured concentrations are not great. Detected levels of phosphorus $(\mathrm{P})$ in the pXRF analysis appear mostly in the lower part of the section (below $150 \mathrm{~cm}$ ), in the deposit older than $2000 \mathrm{BC}$.

The PSV comparison and age-depth curve (dating) for the Lake Huhdasjärvi sediment sequence is presented in
Figs. 3, 4 and 5. It is shown that results from these three independent dating methods agree very well, thus supporting the reliability of the sediment chronology. The P-sequence deposition model was constructed based on ${ }^{137} \mathrm{Cs}$, three AMS radiocarbon dates (Table 1), two pollen dates and 11 PSV age constraints in Oxcal 4.2 (Bronk Ramsey 2008, 2009).

The dating results demonstrate that the Huhdasjärvi sediment sequence covers a continuous sedimentary archive since about $6500 \mathrm{BC}$ with an average deposition rate of $0.36 \mathrm{~mm}$ year $^{-1}$ down to a sediment depth of $313 \mathrm{~cm}$. Given the uncertainties with radiocarbon calibration, varve-based PSV chronology and age-depth modelling, we provide an overall confidence level of $\pm 2 \%$ for the dated sequence seen in Fig. 4, shaded in grey.

\section{Pollen and charcoal records}

The pollen, charcoal data, numerical zonation and palynological richness are presented in Fig. 6. The descriptions of the main events in vegetation and land-use history and charcoal data during the Early Neolithic (5200-3900 BC), Middle Neolithic (3900-3200 BC), and Late Neolithic (3200-1800 BC) are presented in Table 2. The periodization of the Neolithic follows Halinen (2015). The pollen data display the major features of pollen stratigraphy in southeastern Finland (Donner 1971; Hyvärinen 1972), with the colonization of Tilia and Picea as the most distinguishing features. In addition, the pollen data display anthropogenic pollen types (Behre 1981; Vuorela 1986), possibly connected to anthropogenic impact (Table 2).
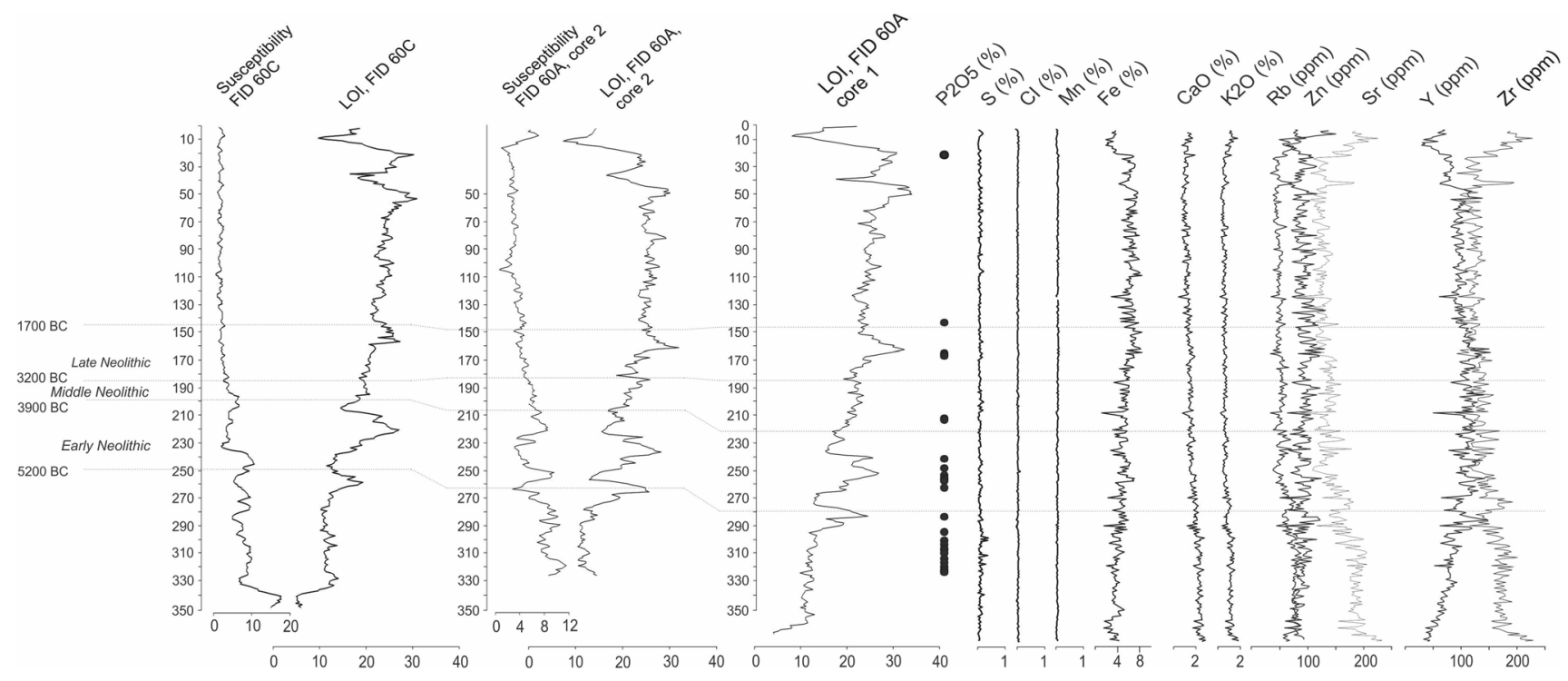

Fig. 2 Characteristics of sediment chemical and physical parameters of the Huhdasjärvi sediment sequence. Geochemistry is measured from FID $60 \mathrm{~A}$, core 1 . The values of $\mathrm{P}$ are presented with dots, meaning presence or absence 
Fig. 3 Lake Huhdasjärvi paleomagnetic age-depth. Records of NRM inclination and declination from the Huhdasjärvi sediment sequence compared with Nautajärvi PSV reference curves (Ojala and Tiljander 2003). Typical features are marked with different letters

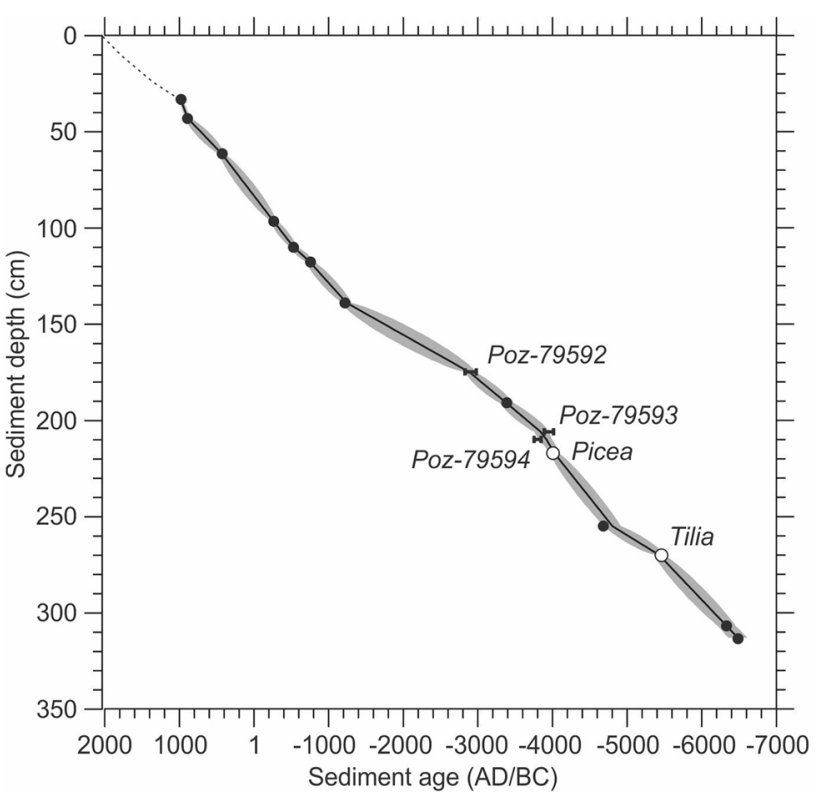

Fig. 4 An age-depth curve of the Huhdasjärvi sediment for coring location FID $60 \mathrm{~A}$ based on the Bayesian P-sequence deposition model with Oxcal 4.2 (Bronk Ramsey 2008, 2009). Calibrated AMS ${ }^{14} \mathrm{C}$ dates $(2 \sigma)$ are indicated with lines, Tilia and Picea chronomarkers with open circles, and tagged PSV characteristics with black circles. The shaded area represents chronological uncertainty levels

The numerical zonation identified four statistically significant zones of major change in the pollen assemblages in FID $60 \mathrm{C}$ and $60 \mathrm{~A}$, based on changes in herb pollen data. In FID $60 \mathrm{C}$, the zone boundaries were at the levels of 153, 185 and $259 \mathrm{~cm}$. In FID $60 \mathrm{~A}$, the zone boundaries were at the levels of 121,185 and $246 \mathrm{~cm}$.

In general, palynological richness remains stable in the study period in both cores. The only fluctuations in
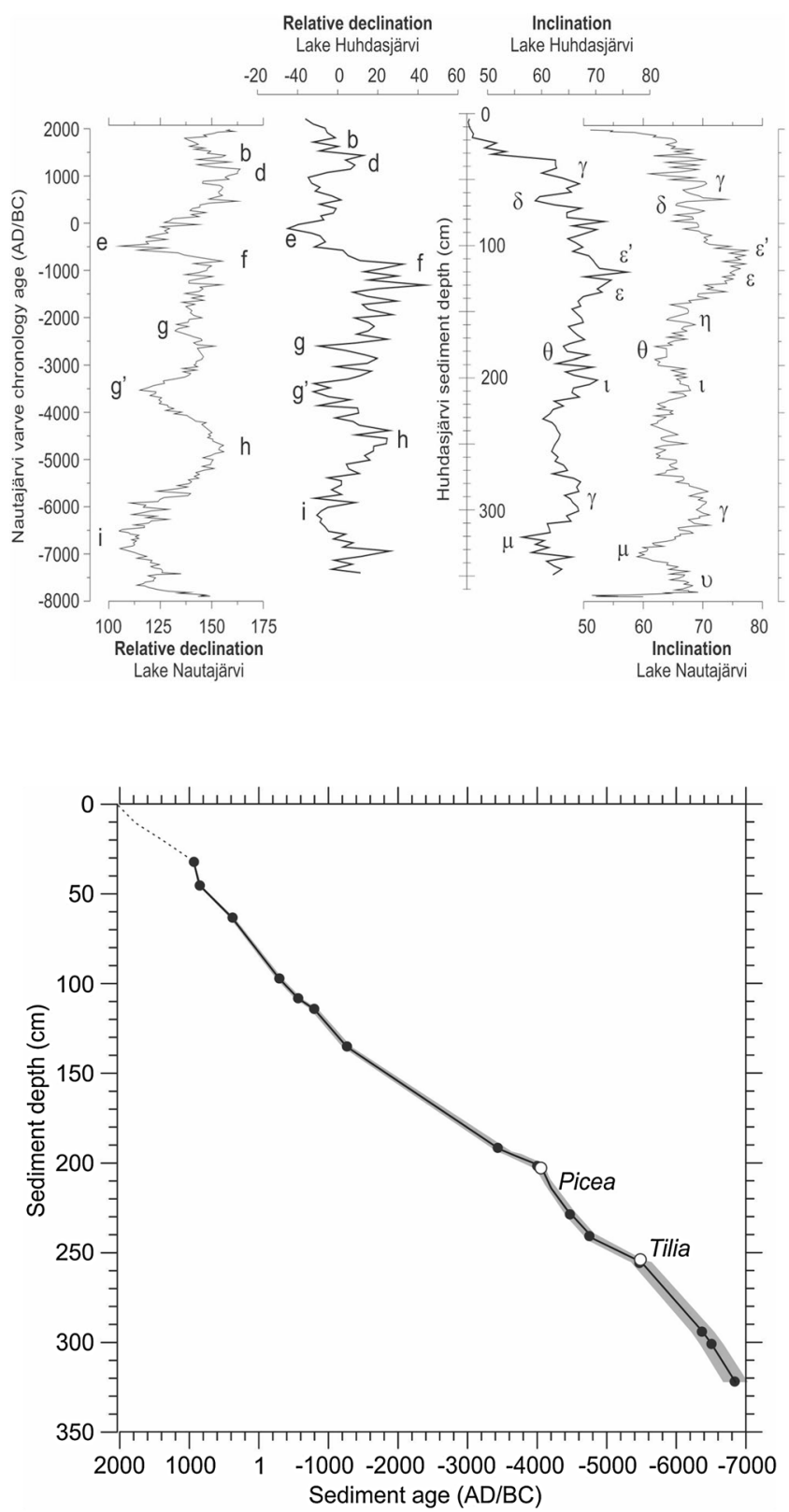

Fig. 5 An age-depth curve of the Huhdasjärvi sediment for coring location FID 60 C. Tilia and Picea chronomarkers are indicated with open circles and tagged PSV characteristics with black circles. The shaded area represents chronological uncertainty levels

palynological richness are visible in the pollen data from core FID $60 \mathrm{C}$, where the rarefacted number of taxa is somewhat lower during the late Mesolithic, until 5600 BC. A slight increase is visible between 208 and $213 \mathrm{~cm}$. The mean charcoal concentration in both cores is highest during the levels of the Early Neolithic, and the mean concentrations decrease in both cores during the Middle Neolithic. Another decrease in charcoal concentration is visible during the Late Neolithic. 


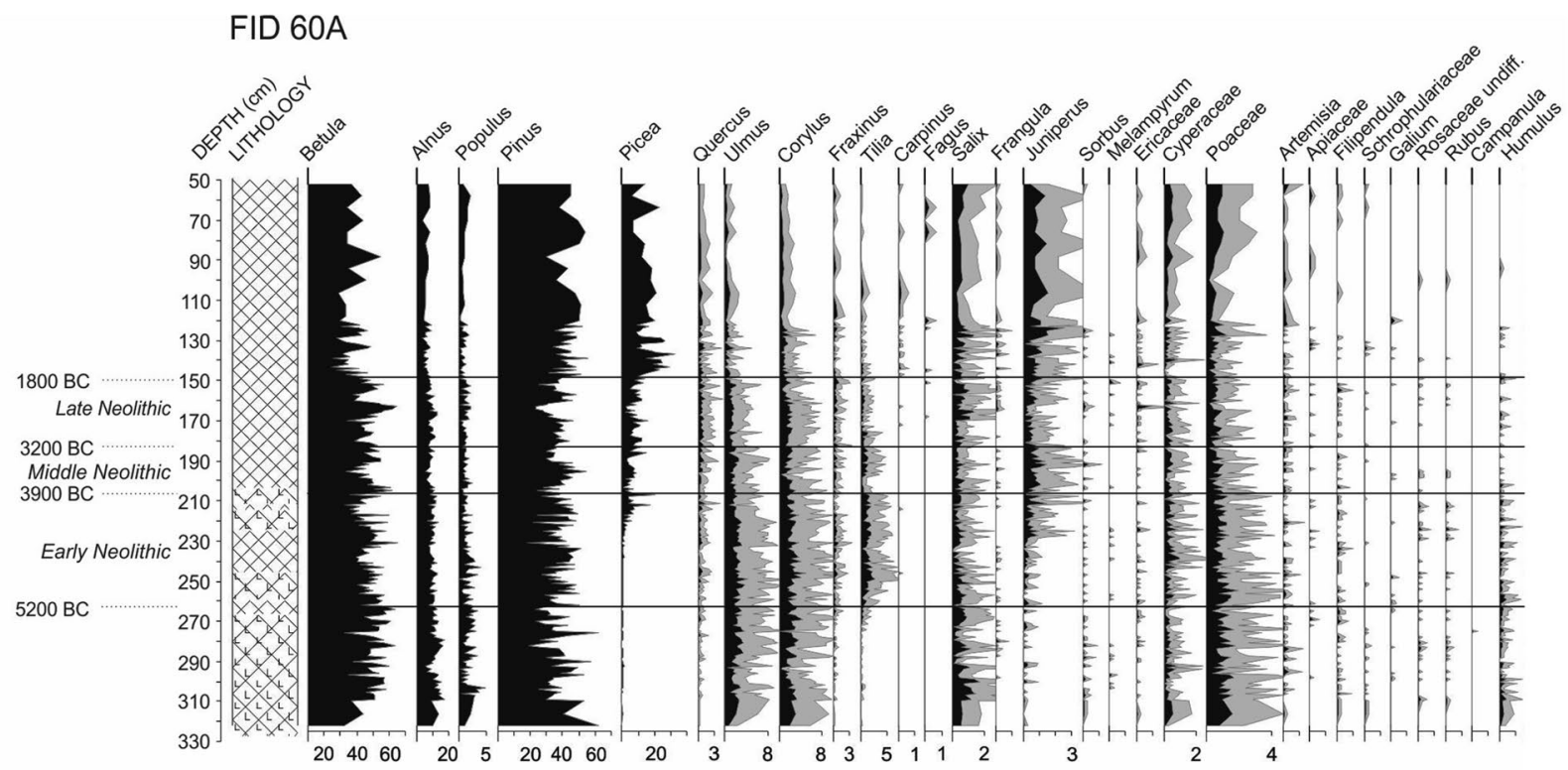

FID 60C

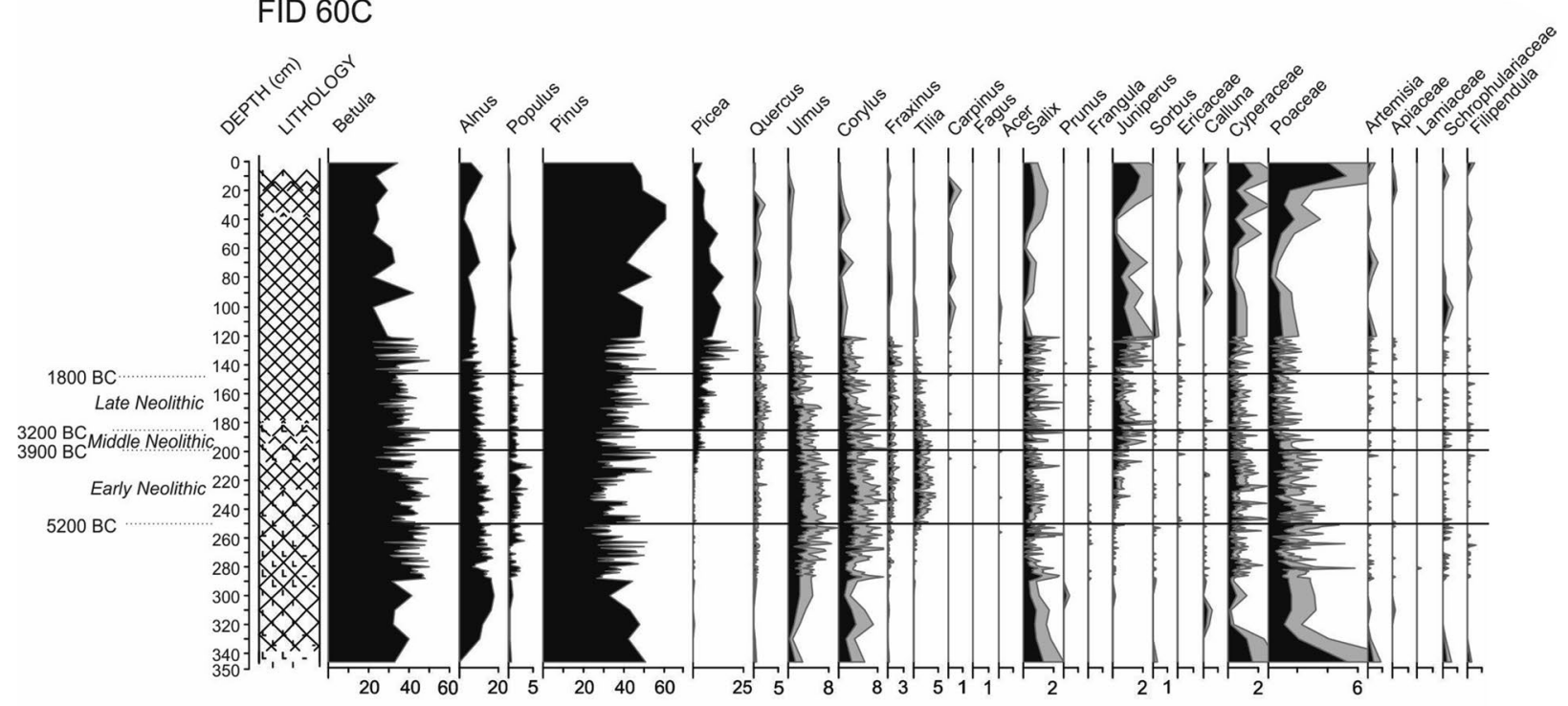

Gyttja Clay gyttja

Fig. 6 Pollen percentages (\%) and charcoal particle concentrations for FID $60 \mathrm{~A}$ and C. Black silhouettes indicate the percentage values and grey silhouettes indicate the exaggeration factor $(\times 2)$. Horizontal

\section{Discussion}

\section{Distinguishing between the pollen of wild Poaceae species and cereals}

It is difficult to make a distinction between the pollen of cultivated cereal crops and that of naturally occurring lines mark the Neolithic periods. ZONISS zones based on herb and cultivated pollen taxa are presented with dashed lines

wild grasses (Tweddle et al. 2005; Behre 2007; Tinner et al. 2007). Behre (2007) has listed species belonging to the Cerealia-type that can be confused with wild grasses. Of these species, Aegilops ovata, Agropyron intermedium, Lygeum spartum, Secale montanum, Triticum aegilopoides, Triticum dicoccoides and Glyceria plicata do not grow in Finland. Bromus erectus, Hordeum 

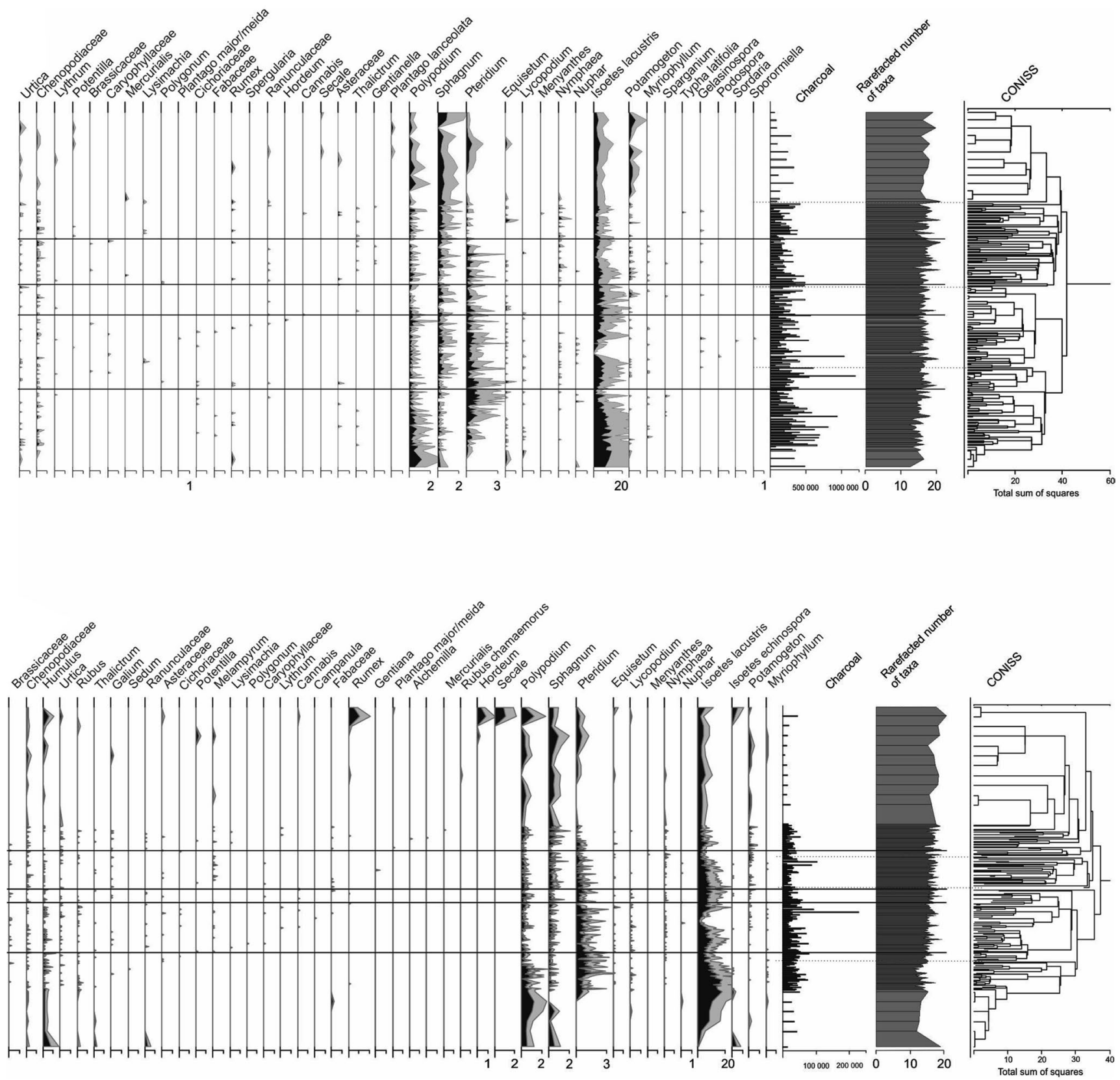

Fig. 6 (continued)

murinum, Setaria pumila and Setaria glauca are all newcomers, appearing in Finland starting from 1950 and even then only occasionally. Also Avena fatua and Bromus inermis are newcomers and rare species in Finland. Bromus mollis only grows in the coastal areas of southern Finland and is only occasionally known from other parts of Finland (Hämet-Ahti et al. 1984). The species that are common in Finland are Agropyron caninum and Glyceria fluitans. Of these, Agropyron caninum grows in groves and grove-like spruce swamps, along brooks and on seashores. As the dominant soil type around Lake Huhdasjärvi is moraine, it seems unlikely that the Cerealia-type pollen originates from Agropyrum caninum. The only species left in Behre's (2007) list that is likely to grow in the surroundings of Lake Huhdasjärvi is Glyceria fluitans. According to the pollen key of Küster (1988), however, the Glyceria type has a diffuse (indistinct) outer annulus boundary, and in our analysis, one important 


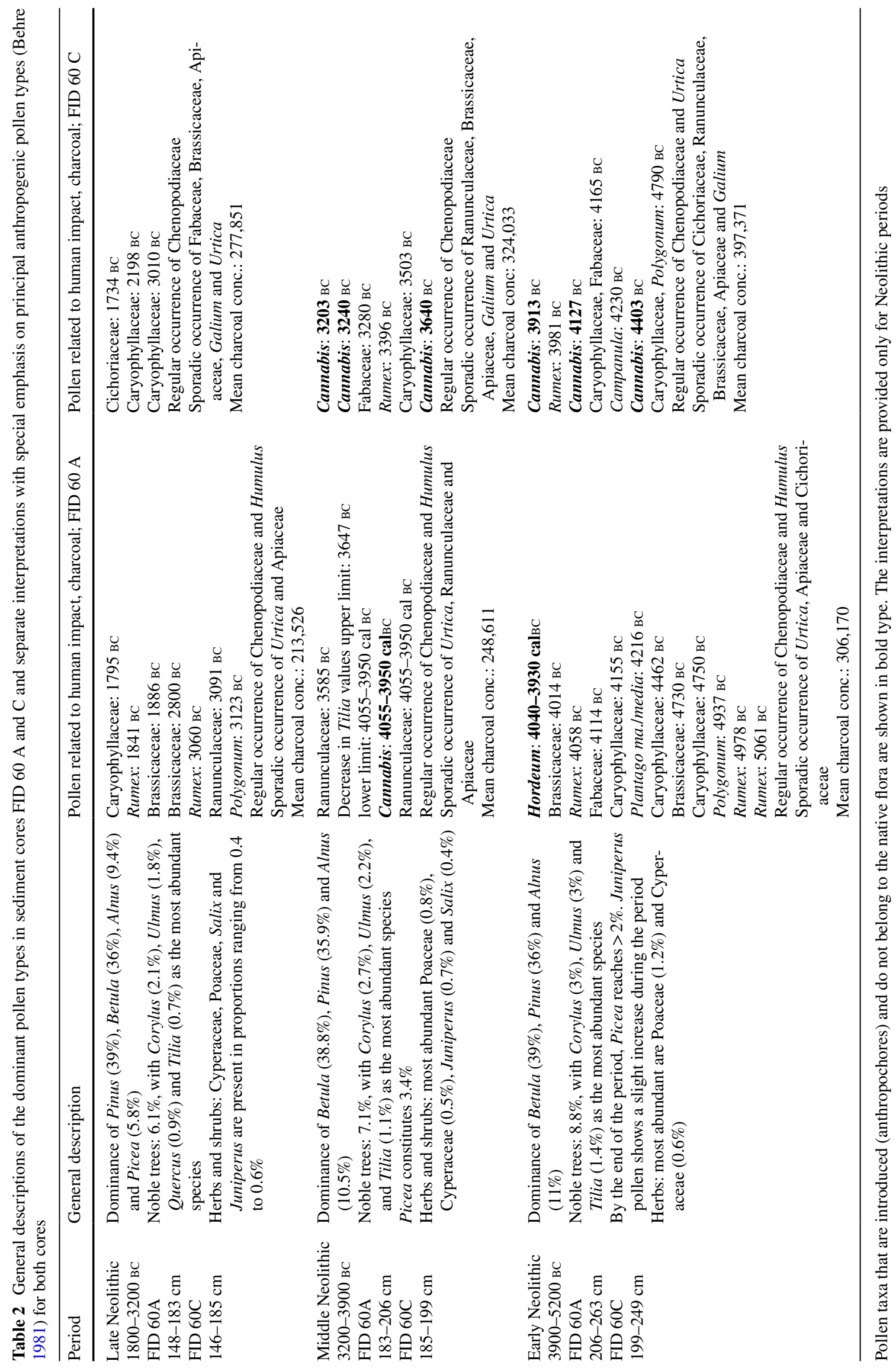


criterion for cereals was an annulus with a distinct outer annulus boundary. It therefore seems unlikely that pollen originating from Glyceria fluitans would have been confused with Cerealia-types.

\section{Geochemical data}

The data accuracy of the geochemical data may be affected by the heterogeneity (e.g. varying density and mineral content) of the sediment samples, as elemental concentrations of unprocessed samples measured by $\mathrm{pXRF}$ are prone to accuracy issues (e.g. Holmqvist 2017). These effects were controlled by performing LOI and focusing on mid- or high-Z elements, which can be more accurately measured by this portable instrument. We can conclude that the data patterns acquired by pXRF are consistent with the results provided by other methods. The concentrations of phosphorus $(\mathrm{P})$ are of interest in relation to human activity. However, $\mathrm{P}$ was rarely detected in our samples, probably due to instrumental limitations in measuring light elements in sediments by pXRF (Hunt and Speakman 2015). Most of the detected $\mathrm{P}$ signals do not correlate with the apparent human activity phases, such as the Iron Age field erosion (at the uppermost ca. $50 \mathrm{~cm}$ ), and thus appear to be linked to natural processes.

For the most part, the detected geochemical signals and variation in the sediment samples represent natural geochemical events and sediment production processes. In the uppermost and lowermost parts of the sediments, the values of $\mathrm{Fe}, \mathrm{Rb}, \mathrm{Zn}, \mathrm{Sr}, \mathrm{Y}$ and $\mathrm{Zr}$ follow the changes in the LOI values. Such changes are typical for early lake stages after isolation and also for recent anthropogenic influence, although it is often not straightforward to interpret them in relation to increased catchment erosion, atmospheric input, and fluctuations in oxygen and redox conditions in the water column (e.g. Bengtsson and Enell 1986).

\section{Fire frequency}

Microscopic charcoal concentration in the Lake Huhdasjärvi sediment records suggests that, apart from a few individual peaks, the general fire activity did not increase significantly during the Neolithic period. In eastern Finland, the mean interval of 220-260 years for forest fires has been recorded at a dry forest site prior to significant human impact between $4300 \mathrm{BC}$ and $\mathrm{AD} 1500$ (Pitkänen et al. 2002), and in central Finland, local fire history studied from a small forest hollow has shown a 430-year return period between 3000 and $1 \mathrm{BC}$ (Clear et al. 2013). This, in general, agrees with fire frequency on the European scale, where sedimentary charcoal records suggest only little fire activity during the Early and Middle Holocene compared to recent millennia (Molinari et al. 2013).

\section{Early Neolithic}

The earliest human impact dates to the Early Neolithic, between ca. 4400 and 3900 BC. It includes some use of fire and cultivation of hemp and barley, as deduced from the occurrence of three Cannabis-type pollen grains from the core obtained from the middle of the bay and one Hordeum-type obtained from the end of the bay and dating to this period. Two peaks in charcoal values, obtained from the middle of the bay, date to ca. 4140 and 4178 BC and are associated with Cannabis-type pollen. More precisely, the Hordeum-type was dated to 4040-3930 cal BC (28) (Poz79,594). A likely explanation for the sudden erosion phase, visible in LOI and susceptibility values between 4090 and 4165 , is the land use activity around the lake. The land use activity has also generated new biotopes, deduced from a slight increase in the rarefacted number of taxa between 4200 and $4140 \mathrm{BC}$, visible in the pollen record obtained from the middle of the bay. In addition to the cultivated plants Hordeum and Cannabis, apophytes such as Plantago major/media, Rumex, Fabaceae, Campanula and Caryophyllaceae are recorded. Of these, Plantago major/media is a plant species that is associated with more or less nitrogenrich footpaths and ruderal communities (Behre 1981).

As discussed above, the misidentification of Cerealiatype as pollen belonging to wild grasses seems unlikely, as most of the wild grasses that produce pollen similar to that of Cerealia-types either do not grow in Finland at all or are newcomers from 1950 onwards. Also Glyceria fluitans, a species common in Finland, can clearly be separated from Cerealia-type by its indistinct outer annulus boundary. However, if we assume that Cerealia-type pollen did in fact originate from wild grasses, one might expect to find this pollen evenly scattered through the Holocene, also in the Mesolithic period. In Lake Huhdasjärvi, no pollen of Cerealia-type dating to the Mesolithic period has been found. Furthermore, the dating (4040-3930 cal BC) of the Hordeum-type closely agrees in age with the former analysis from the lake (Alenius et al. 2013), where a single occurrence of Hordeum pollen was dated to ca. 4260 BC. The dates for the Hordeum-type also agree in age with the wider context in Finland, Estonia and the Karelian Republic in Russia, where the earliest cultivation dates to the Early and Middle Neolithic (between 4300 and 3200 BC) (Tolonen 1978; Vuorela et al. 2001; Poska et al. 2004; Poska and Saarse 2006; Kriiska 2009; Mökkönen 2010; Nordqvist and Kriiska 2015). It also seems unlikely that Cerealia-type pollen from more recent layers could have been included in the samples as down-core intrusions. In all cores from Lake Huhdasjärvi, the outer parts of the cores were first removed and the sample for pollen analysis was obtained from the middle of the sediment core. 
In addition to misidentification, one potential source of error concerns the datings. In this work, the dating was based on two independent dating methods, namely palaeomagnetic dating and ${ }^{14} \mathrm{C}$ dating. As these two methods gave similar results for the Hordeum-type, we have no reason to doubt the datings. In the first analysis (Alenius et al. 2013), the chronology was based on ${ }^{14} \mathrm{C}$ datings. Because of the absence of limestone in the local bedrock, we do not expect a freshwater reservoir effect (Olsson 1986) to be a factor affecting radiocarbon ages.

\section{Middle Neolithic}

After the Early Neolithic land use, direct evidence of human activity again becomes visible during the Middle Neolithic, in the pollen analysis obtained from the end of the Pitkälahti bay (FID 60 A). A sudden and atypical decrease in Tilia pollen values starts at ca. $4000 \mathrm{BC}(\mathrm{Poz}-79,593)$ and is connected with a single Cannabis-type pollen grain. In our charcoal data, it seems reasonable to assume that the peak at the level of $3890 \mathrm{BC}$ is locally human-induced, as this coincides with the onset of the abrupt decrease in lime trees. The decrease in Tilia then lasts about 350 years until ca. 3650 BC. In contrast to a natural, long, and gradual process, where Tilia was replaced by Picea during the Middle and Late Neolithic (Seppä et al. 2009) due to their overlapping ecological niches, the decrease in Tilia in the Lake Huhdasjärvi diagram is very abrupt. Coinciding with the start of decrease in Tilia, a clear increase in Juniperus values is recorded from са. 4000 вс until ca. 3200 вс. A plausible explanation is forest clearing, which increased light and open patches in the forest, creating a favourable environment for this shade-intolerant species. After the ca. 350 years of Tilia use around the end of the bay, direct evidence of human activity can again be seen in the core obtained from the central part of the bay, where three Cannabis-type and one Rumex are recorded from the layers dating between ca. 3640 and 3200 вс.

The ${ }^{14} \mathrm{C}$ dates taken at the depths of 206 and $210 \mathrm{~cm}$ in FID 60 A show a very minor reversal (Fig. 4; Table 1). In the LOI, there is a peak in mineral matter content, and also in geochemistry, small decreases in $\mathrm{Zr}, \mathrm{Sr}$ and $\mathrm{Zn}$ values are recorded around $206 \mathrm{~cm}$. The minor reversal in the ${ }^{14} \mathrm{C}$ result could then be explained by instability in the catchment through disturbance, likely caused by people.

It is worth noting that in addition to human activity, also natural disturbance dynamics, such as wind throw, natural animal/plant interactions, diseases or natural forest fires can create openings within the canopy that could have replaced Tilia and generated niches within which Juniperus could grow. In this case, interpreting the change to have been caused by human impact rather than natural disturbance dynamics is supported by the simultaneous occurrence of several Cannabis-type pollen finds in the pollen data. This species is not native to Finland, but has been introduced to the area. The misidentification of Humulus as Cannabis seems unlikely, as in our analysis, the size limit of Cannabis was set to $\geq 30 \mu \mathrm{m}$, a criterion that is higher than that recommended by most authors. If one assumes that the pollen identified as Cannabis actually originated from Нитиlus, one might expect this pollen to be scattered evenly in the sediment. However, in Lake Huhdasjärvi, all the Cannabis-type pollen grains date to the Neolithic, between 4400 and $3200 \mathrm{BC}$.

\section{Hemp and lime}

Both hemp and lime are known to be an important source of bast fibres. Coarse hemp textiles have been used for different purposes and strong hemp fibre is especially well suited for making ropes. In addition to providing fibre, hemp is also a food plant: for humans, it is an oil-producing plant with edible seeds that could be consumed as a raw or roasted whole grain snack, and for animals, it can be used as fodder (Barber 1991; Mannering et al. 2012; Clarke and Merlin 2013; Zohary et al. 2013).

The domestication of hemp had taken place in central Asia, probably in the southern margin of the taiga forest or the forest steppe region (Clarke and Merlin 2013; Zohary et al. 2013; Long et al. 2017) and it does not belong to the natural vegetation in Finland. Hemp is proposed as having spread into Europe in two main stages:

1. The earliest distribution to Europe is dated to the Neolithic, ca. 5000 вС, as shown by a few Linearbandkeramik sites, one in Romania and another in Germany, which have produced charred hemp seeds and hemp seed imprints in pottery

2. The second stage, connected to the spread of the peoples from the Eurasian steppe, dates to about 3500 $3000 \mathrm{BC}$ and probably also included the use of narcotic species, (Sherratt 1991; Mallory and Adams 1997; Clarke and Merlin 2013).

The early Cannabis species found in northern Europe and in the northern part of eastern Europe were most likely species with a notably low psychoactive chemical content, which were not as suitable for use as drugs as a few other Cannabis species with a more southern and eastern distribution (Clarke and Merlin 2013). The early European utilization of hemp was likely concentrated on the production of fibres and seeds, as it was during the early phase in eastern Asia (Clarke and Merlin 2013). In the eastern part of the Baltic Sea, pollen and seeds of hemp were present early on. The earliest hemp pollen is dated to the transition between the Mesolithic and Neolithic Stone Ages and the Early Neolithic_-in Estonia ca. 5600 BC (Poska and Saarse 
2006). Further to the south, the evidence for hemp is a bit more recent. In Latvia, hemp seeds have been found at the Sãrnate dwelling site (Vasks et al. 1999). The pottery found at the Sãrnate site represents Early and Late Sãrnate Ware, with some Typical Comb Ware as well as Late Comb Ware, and the complex is dated to ca. 4300-2900 BC (Bērziņš 2008). In Lithuania, a wider spectrum of evidence is provided from the wetland dwelling sites in Šventoji. At the Šventoji 3 site, hemp seeds were recovered, and at the Šventoji 23 site, hemp seeds and pollen were detected, and even a piece of hemp rope was discovered in the layers of the dwelling site (Rimantienè 1979, 1999, 2005, but see also the critical discussion of these finds in Piličiauskas et al. 2017). The former site is dated to $3200-2500 \mathrm{cal} \mathrm{BC}$, and the latter to 2900-2000 cal BC (Rimantienè 2005).

Tilia bast was widely in use as a raw material for different textiles and cordage during the Stone Age. Textiles made of lime bast have been found, for example, in Neolithic Denmark (Bender Jørgensen 1990; Mannering et al. 2012), and plenty of carbonized debris from the extraction of bast fibres has been discovered in central Europe (Schweingruber 1990). In the Baltic States, bast fibre products include cordage, mats or clothes, fishing nets and braided baskets, which were used in addition to products made of birch bark and fibres of nettle and hemp. Such artefacts have been found, for example, at the Šventoji sites, Lithuania, dated to ca. 4000-2000 BC (Rimantienè 2005; Rimkuté 2010). In addition, imprints of different textiles in pottery since the third millennium $\mathrm{BC}$ show indirect evidence for Neolithic textiles in Estonia (Kriiska et al. 2005). In Finland, archaeological data does not include any Stone Age artefacts made of Tilia bast, even if such artefacts must certainly have been used, and the imprints of any kind of textiles in pottery are rather limited and date no earlier than the Late Neolithic (Lavento 2001).

\section{Late Neolithic}

In our new pollen data, there is no prominent human impact on vegetation after ca. $3200 \mathrm{BC}$ during the Late Neolithic (3200-1800 BC). Interestingly, the Pukkisaari housepit site, situated on a small island in the middle of Lake Huhdasjärvi, with Pöljä Ware and some poorly known Neolithic pottery, dates to 3020-2890 cal вс (Alenius et al. 2013). This period, then, seems to be connected with the people who used Pöljä Ware pottery and built the largest housepits in the area. Although direct evidence of human impact is absent, there is, however, a phase of increased charcoal concentration visible in the core obtained from the end of the bay, lasting from ca. 3370 to $2970 \mathrm{BC}$. In addition, two peaks in charcoal data in the core obtained from the middle of the bay date to ca. 2275 and 2160 вс. With the exception of these, a low charcoal concentration indicates only low fire activity in the area. A clear increase in organic matter input into the bay is detected at both coring sites between ca. 2600 and $1840 \mathrm{BC}$, the highest peak in organic content dating to ca. 2300 вс. This could be connected to a slight eutrophication of the lake. Coincident with the organic peak, the measured Yttrium (Y) proportional values also peak in the geochemical data, also possibly associated with changes in trophic level. After ca. 2300 вC, a decreasing trend in the concentration values of $\mathrm{Sr}, \mathrm{Rb}, \mathrm{Y}$ and $\mathrm{Zr}$ can be seen, possibly connected to the diminishing land use in the surroundings of the lake. After ca. $2300 \mathrm{BC}$, also the measured $\mathrm{Fe}$ (and possibly $\mathrm{Zn}$ ) values are consistently higher than in earlier sediment layers.

In addition to geochemical changes in the sediment, which may possibly be associated with the trophic level and later with decreasing land use in the surroundings of the lake, there are changes in the CONISS zonation, indicating a change in herb vegetation in the surroundings of the bay. In the CONISS zonation in FID $60 \mathrm{C}$, one major division was dated to ca. $1965 \mathrm{BC}$, that is, close to the transition between the Late Neolithic and Early Metal Period according to Finnish periodization. This transition period is characterized by a scarcity of archaeological remains in the Finnish inland in general (Taavitsainen et al. 1998; Lavento 2001, 2015), as well as around Lake Huhdasjärvi.

Despite the scarcity of archaeological remains in the Late Neolithic period (between 2500 and 2100 BC) in Finland, this is the phase which in Finland and Estonia in general show quite a diverse range of evidence connected to agriculture, evidently indicating that the custom of cultivation was becoming more common in the Northern Boreal Zone (Tolonen 1980; Alenius 2008; Alenius et al. 2009; see also; Vuorela 1999). In the earlier study, a single Hordeum-type was found at the level dating to ca. $2160 \mathrm{BC}$ from Lake Huhdasjärvi. Further, the earliest macrofossil evidence for cultivation (Vuorela and Lempiäinen 1988; see also; Vanhanen and Pesonen 2015), biomarker lipids and $\delta^{13}$ values have revealed the presence of milk in pottery around $2500 \mathrm{BC}$ (Cramp et al. 2014). Also, the earliest bone of sheep/goat recovered from a dwelling site of the Kiukainen Culture (ca. 2200-1950 BC) in southern Finland (Bläuer and Kantanen 2013) dates to this transition period, which shows quite a diverse range of evidence connected to agriculture.

\section{Conclusions}

In general, all three independent studies provided similar sedimentary data and pollen data describing the vegetation development in the region, such as the spread of Tilia 
and Picea abies to eastern Finland from ca. 5400 BC and $4100 \mathrm{BC}$ onwards. Based on the empirical studies, the relevant source area (RSAP; Sugita 1994, 1998) of pollen is ca. 1,500-2,000 $\mathrm{m}$ in similarly sized sites (Sugita et al. 2010; Poska et al. 2011). As the distance between the coring sites is about $450 \mathrm{~m}$, the source areas of all the sediment cores partially overlap. There are, however, clear differences in the pollen data that can be connected to local vegetation. Six of altogether seven Cannabis-type pollen findings originated from the sediment core that was obtained from the middle of the bay, indicating that hemp cultivation has been practiced somewhere around the central part of the bay rather than around the end of the bay, whereas the use of Tilia trees was only visible in the pollen analysis obtained from the end of the Pitkälahti bay. These differences indicate that the archaeological sites were small in size and land use was very local in origin and concentrated on different areas during different periods, resulting in differences in the vegetation.

The earliest human impact, only detected in the earlier pollen analysis (Alenius et al. 2013), dated to the very beginning of the Neolithic, 5370-5060 cal BC, when a single pollen find indicated the cultivation of Fagopyrum esculentum by the lake. This was connected to forest clearance, deduced from the simultaneous and abrupt decrease of Betula and Pinus and increase in charcoal concentration. In archaeology, this phase refers to Early Comb Ware, style I:1. No pollen originating from Fagopyrum esculentum was found in the new analyses. This is not surprising, as this is an entomophilous cross-pollinating plant in which pollen is carried from the anther of one flower to the stigma of another by insects. It has large dimorphic pollen grains $(60 \times 35 \mu \mathrm{m}$ in brevistyled and $45 \times 24 \mu \mathrm{m}$ in longistyled flowers) (Erdtman et al. 1961). Although pollen grains originating from Fagopyrum esculentum are occasionally found in sediments, they are always rare in the pollen rain (de Klerk et al. 2015).

The most active land use phase can be seen in all three pollen diagrams and dates to between ca. 4400 and 3200 BC. According to new pollen analyses, an important part of the human activity seems to be connected to producing fibres from hemp and lime. Cannabis-type pollen was found in the layers dating to 4400 and 3200 BC, and the utilization of lime trees dates to between ca. 3890 and 3650 BC. Hordeum-type pollen date to ca. 4260 BC and to $3960 \mathrm{cal} \mathrm{BC}$. The mosaic of land use activities has resulted in an increase in open patches in the forest, in which Juniperus, which demands light, and other apophytes such as Plantago major/media, Caryophyllaceae and Rumex can grow.

In the surroundings of Lake Huhdasjärvi, the beginning of hemp and barley cultivation and beginning of lime use roughly dates to the turn of the 5th and 4th millennia $\mathrm{BC}$, when the Younger Early Comb Ware, style 1:2, was to be overridden by the subsequent pottery style, Typical Comb Ware (3900-3500 BC). The appearance of the first Cannabis and Hordeum pollen during this particular time is not unexpected, as this period shows increasing evidence of cultivation and human impact on vegetation within the sphere of Typical Comb Ware distribution (Kriiska 2009; Mökkönen 2010). In addition, this period is associated with a profound cultural change, which spread rapidly over vast areas in the north-north-eastern European forest zone through highly active contact networks that incorporated new technologies, new raw materials, and obviously new ideas that affected the way people engaged with the material world (Núñez and Okkonen 2005; Mökkönen 2011; Herva et al. 2014, 2017; Nordqvist and Kriiska 2015; Nordqvist et al. 2015). At the same time, sedentary habitation in village-like arrangements of pithouses became established (Zhul'nikov 1999, 2003; Núñez and Okkonen 2005; Vaneeckhout 2009; Mökkönen 2011), a high tide of rock art was about to begin (Lahelma 2008; Gjerde 2010), and the number of furnished burials with intense red-ochre usage increased (Halinen 1999; Zagorska 2006, 2008). Although not all of these phenomena are found in the current study area, these changes are part of the Neolithization process that took place in the north-north-eastern European boreal forest zone (Herva et al. 2014, 2017; Nordqvist and Kriiska 2015).

The actual crop cultivation was small scale and sporadic, and did not play a significant role as a subsistence source. Osteological data (Ukkonen 1996; Mökkönen 2001; Nurminen 2007; Seitsonen et al. 2017), fishing structures (Koivisto and Nurminen 2015) and lipid analysis (Cramp et al. 2014), all beyond the 60th parallel north, suggest that the subsistence base was aquatically oriented in the economy of Neolithic populations. Various nuts, fruits, roots and seeds, such as hazel, water chestnut, dropwort and wild strawberry were gathered in Finland during the Stone Age (Vanhanen and Pesonen 2015). Evidently, the period from the introduction of cultivation to the point where it actually acted as a key factor in subsistence in north-eastern European boreal forests was a long-term process that took several thousands of years.

Acknowledgements The study was financed by the Academy of Finland through the Academy Research Fellow project "Land use, cultivation and animal husbandry during the Neolithic in North-Eastern Europe between c. 6000 and 1000 BC" granted to Teija Alenius (project 274851). Teemu Mökkönen was financed by the Academy of Finland for the project "The use of materials and the Neolithisation of north-east Europe (ca. 6000-1000 BC)", University of Oulu (20132017). Many thanks to Krista Vajanto for discussions concerning the textiles and fibres. We acknowledge the helpful comments by two anonymous reviewers. Language revision was provided by Sarianna Silvonen. 
Open Access This article is distributed under the terms of the Creative Commons Attribution 4.0 International License (http:// creativecommons.org/licenses/by/4.0/), which permits unrestricted use, distribution, and reproduction in any medium, provided you give appropriate credit to the original author(s) and the source, provide a link to the Creative Commons license, and indicate if changes were made.

\section{References}

Alalammi P (1987) Atlas of Finland, 131: climate. Geographical Society of Finland, Helsinki

Alalammi P (1988) Atlas of Finland, 141: vegetation and flora. Geographical Society of Finland, Helsinki

Alenius T (2008) Appendix 2: The palaeoecological study of three mires on the island Kemiönsaari, SW Finland. In: Asplund $\mathrm{H}$ (ed) Kymittæ. Sites, centrality and long-term settlement change in the Kemiönsaari region in SW Finland. Turun yliopiston julkaisuja. Annales Universitatis Turkuensis Ser. B Tom 312: Humaniora. Turun Yliopisto, Turku

Alenius T, Lavento M, Saarnisto M (2009) Pollen-Analytical Results from Lake Katajajärvi-Aspects of the History of Settlement in the Finnish Inland Regions. Acta Borealia 26:136-155

Alenius T, Mökkönen T, Lahelma A (2013) Early farming in the northern boreal zone: reassessing the history of land use in south eastern finland through high-resolution pollen analysis. Geoarchaeol 28:1-24

Augustsson A, Gaillard M-J, Peltola P, Mazier F, Bergbäck B, Saarinen T (2013) Effects of land use and climate change on erosion intensity and sediment geochemistry at Lake Lehmilampi, Finland. Holocene 23:1,247-1,259

Barber EJW (1991) The archaeolinguistics of hemp, in Prehistoric Textile: The Development of Cloth in the Neolithic and Bronze Ages. Princeton University Press, Princeton

Behre K-E (1981) The interpretation of anthropogenic indicators in pollen diagrams. Pollen Spores 23:225-245

Behre K-E (2007) Evidence for Mesolithic agriculture in and around central Europe? Veget Hist Archaeobot 16:203-219

Bender Jørgensen L (1990) Stone Age textiles in Northern Europe. In: Walton P, Wild JP (eds) Textiles in Northern Archaeology: NESAT III: textile Symposium in York 6-9 May 1987. Archetype Publishers, London, pp 1-10

Bengtsson L, Enell M (1986) Chemical analysis. In: Berglund BE (ed) Handbook of Holocene palaeoecology and palaeohydrology. Wiley, Chichester, pp 423-454

Bennett KD, Willis KJ (2001) Pollen. In: Smol JE, Birks HJB, Last WM (eds) Tracking environmental change using lake sediments, vol 3. Kluwer, Dordrecht, pp 5-32

Bērziņš V (2008) Sārnate: living by a coastal lake during the East Baltic Neolithic. Acta Universitatis Ouluensis B 86. University of Oulu, Oulu

Beug H-J (2004) Leitfaden der Pollenbestimmung für Mitteleuropa und angrenzende Gebiete. Pfeil, München

Birks HJB, Line JM (1992) The use of rarefaction analysis for estimating palynological richness from quaternary pollenanalytical data. Holocene 2:1-10

Bläuer A, Kantanen J (2013) Transition from hunting to animal husbandry in Southern, Western and Eastern Finland: new dated osteological evidence. J Archaeol Sci 40:1,646-1,666

Boivin N, Fuller D, Crowther A (2012) Old World globalization and the Columbian exchange: comparison and contrast. World Archaeol 44:452-469
Bronk Ramsey C (2009) Bayesian analysis of radiocarbon dates. Radiocarbon 51:337-360

Bronk-Ramsey C (2008) Deposition models for chronological records. Quat Sci Rev 27:42-60

Carpelan C (1999) Kääannekohtia Suomen esihistoriassa aikavälillä 5100-1000 eKr. In: Fogelberg P (ed) Pohjan poluilla: suomalaisten juuret nykytutkimuksen mukaan. Bidrag till kännedom av Finlands natur och folk 153. Societas Scientiarum Fennica, Helsinki, pp 249-280

Clarke RC, Merlin MD (2013) Cannabis: evolution and ethnobotany. University of California Press, Berkley

Clear JL, Seppä H, Kuosmanen N, Bradshaw RHW (2013) Holocene fire frequency variability in Vesijako, Strict Nature Reserve, Finland, and its application to conservation and management. Biol Conserv 166:90-97

Cramp LJE, Evershed RP, Lavento M, Halinen P, Mannermaa K, Oinonen M, Kettunen J, Perola M, Onkamo P, Heyd V (2014) Neolithic dairy farming at the extreme of agriculture in northern Europe. Proc R Soc B 281:20140819

Davidson K, Dolukhanov PM, Sarson GR, Shukurov A, Zaitseva GI (2009) Multiple sources of the European Neolithic: mathematical modelling constrained by radiocarbon dates. Quat Int 203:10-18

Davis LG, Macfarian SJ, Henrickson CL (2012) A PXRF-based Chemostratigraphy and Provenience System for the Cooper's Ferry Site, Idaho. J Archaeol Sci 39:663-671

De Klerk P, Couwnberg J, Joosten H (2015) Pollen and macrofossils attributable to Fagopyrum in western Eurasia prior to the Late Medieval: An intercontinental mystery. Palaeogeogr Palaeoclimatol Palaeoecol 440:1-21

Donner JJ (1971) Towards a stratigraphical division of the Finnish Quaternary. Comment Phys-Math 41:281-305

Erdtman G, Berglund B, Praglowski J (1961) An introduction to a Scandinavian pollen flora. Grana Palynologica 2:3-86

Fægri K, Iversen J (1989) In: Fægri K, Kaland POE, Krzywinski K (eds) Textbook of pollen analysis, 4th edn. Wiley, Chichester

Gepts TR, Famula TR, Bettinger RL, Brush SB, Damania AB, McGuire PE, Qualset CO (2012) Biodiversity in agriculture: domestication, evolution and sustainability. Cambridge University Press, Cambridge

Gjerde JM (2010) Rock art and landscapes: studies of Stone Age rock art from northern Fennoscandia. PhD dissertation, Department of Archaeology and Social Anthropology, University of Troms\&\#248

Grimm E (1987) CONISS: a Fortran 77 program for stratigraphically constrained cluster analysis by the method of incremental sum of squares. Comput Geosci 13:13-35

Grimm EC (1991) TILIA and TILIA-GRAPH. Illinois State Museum, Springfield

Halinen P (2015) Kivikausi. In: Haggrén G, Halinen P, Lavento M, Raninen S, Wessman A (eds) Muinaisuutemme jäljet. Suomen esi-ja varhaishistoria kivikaudelta keskiajalle. Gaudeamus, Helsinki, pp 367-536

Hämet-Ahti L, Suominen J, Ulvinen T, Uotila P, Vuokka S (1984) Retkeilykasvio. Suomen luonnonsuojelun tuki. Helsinki

Herva V-P, Nordqvist K, Lahelma A, Ikäheimo J (2014) Cultivation of Perception and the Emergence of the Neolithic World. Nor Archaeol Rev 47:141-160

Herva V-P, Mökkönen T, Nordqvist K (2017) A northern Neolithic? Clay work, cultivation and cultural transformations in the Boreal zone of North-Eastern Europe, c.5300-3000 BC. Oxf J Archaeol 36(1):25-41

Holmqvist E (2017) Portable Hand-held X-ray fluorescence spectrometry (pXRF). In: Hunt AMW (ed) The oxford handbook of archaeological ceramic analysis. Oxford University Press, Oxford, pp 363-381 
Hunt AMW, Speakman RJ (2015) Portable XRF analysis of archaeological sediments and ceramics. J Archaeol Sci 53:626-638

Hyvärinen H (1972) Flandrian regional pollen assemblage zones in eastern Finland. Commentationes Biologicae 59. Societas Scientiarium Fennica, Helsinki

Janik L (2002) Wandering weed: The journey of buckwheat (Fagopyrum sp.) as an indicator of human movement in Eurasia. In: Boyle K, Renfrew C, Levine M (eds) Ancient interactions: East and west in Eurasia. McDonald Institute of Archaeology, Cambridge, pp 299-308

Jones M, Hunt H, Lightfoot E, Lister D, Liu X, Motuzaite-Matuzeviciute $G$ (2011) Food globalization in prehistory. World Archaeol 43:665-675

Jordan P, Zvelebil M (2010) Ex oriente lux: The prehistory of huntergatherer ceramic dispersals. In: Jordan P, Zvelebil M (eds) Ceramics before farming: The dispersals of pottery among prehistoric Eurasian hunter-gatherers. Left Coast Press, Walnut Creek, pp 31-89

King J, Peck J (2001) Use of paleomagnetism in studies of lake sediments. In: Last WM, Smol JP (eds) Tracking environmental change using lake sediments, vol 1. Kluwer, Dordrecht, pp 371-389

Kinnunen K, Tynni R, Hokkanen K, Taavitsainen J-P (1985) Flint Raw Materials of Prehistoric Finland: Rock Types, Surface Structures and Microfossils. Geological Survey of Finland, Bulletin 334. Geological Survey of Finland, Espoo

Koivisto S, Nurminen K (2015) Go with the flow: stationary wooden fishing structures and the significance of Estuary fishing in subneolithic Finland. Fennoscandia Archaeologica 32:55-77

Königsson LK, Possnert G, Hammar T (1997) Economical and cultural changes in the landscape development at Novgorod, Russia. Tor 29:353-382

Kriiska A (2003) From hunter-fisher-gatherer to farmer-changes in the Neolithic economy and settlement on Estonian territory. Archeologia Liuana 4:11-26

Kriiska A (2009) The beginning of farming in the Eastern Baltic. In: Dolukhanov PM, Sarson GR, Shukurov AM (eds) The East European Plain on the Eve of Agriculture. BAR International Series 1964. Archaeopress, Oxford, pp 159-180

Kriiska A, Lavento M, Peets J (2005) New AMS dates of the Neolithic and Bronze Age ceramics in Estonia: preliminary results and interpretations. Estonian J Archaeol 9:3-31

Küster H (1988) Vom Werden einer Kulturlandschaft: vegetationsgeschichtliche Studien am Auerberg (Südbayern). Acta Humaniora, Weinheim

Lahelma A (2008) A touch of Red: Archaeological and Ethnographical Approaches to Interpreting Finnish Rock Paintings. Iskos 15. Finnish Antiquarian Society, Helsinki

Lavento M (2001) Textile ceramics in Finland and on the Karelian Isthmus. Suomen muinaismuistoyhdistyksen aikakausikirja 109. Suomen Muinaismuistoyhdistys, Helsinki

Lavento M (2015) Pronssi- ja varhaismetallikausi. In: Haggrén G, Halinen P, Lavento M, Raninen S, Wessman A (eds) Muinaisuutemme jäljet. Suomen esi-ja varhaishistoria kivikaudelta keskiajalle. Gaudeamus, Helsinki, pp 125-212

Long T, Wagner M, Demske D, Leipe C, Tarasov PE (2017) Cannabis in Eurasia: origin of human use and Bronze Age transcontinental connections. Veget Hist Archaeobot 26:245-258. doi:10.1007/s00334-016-0579-6

Mallory JP, Adams DQ (eds) (1997) Encyclopedia of Indo-European Culture. Fitzroy Dearborn Publishers, London and Chicago

Mannering U, Gleba M, Bloch Hansen M (2012) Chap. 3: Denmark. In: Mannering U, Gleba M (eds) Textiles and textile production in Europe: from prehistory to $\mathrm{AD} 400$. Ancient Textiles Series 11. Oxbow Books, Oxford, pp 138-150
Miettinen T (1998) Kymeenlaakso esihistoriaa. Kymenlaakson maakuntamuseon julkaisuja 26. Painokotka, Kotka

Miettinen T (2004) Jaalan esihistoria. In: Salminen E, Hamari R, Miettinen $\mathrm{T}$ (eds) Jaalan historia: Vesikansan vaiheet muinaisista ajoista 2000-luvulle. Jaalan kunta, Jaala, pp 89-131

Miettinen T (2012) Kymenlaakson esihistoriallinen kehitys. In: Kaukiainen Y (ed) Kymenlaakson historia 1: Jokolaakso ja rajamaa esihostoriasta 1810-luvulle. Suomalaisen kirjallisuuden seura, Helsinki, pp 30-79

Mökkönen T (2001) Hauki on kala-Saimaan vesistöalueen kivi- ja varhaismetallikautinen osteologinen aineisto. Muinaistutkija 3/2001:2-13

Mökkönen T (2002) Chronological variation in the locations of hunter-gatherer occupation sites vis-à-vis the environment. In: Ranta $\mathrm{H}$ (ed) Huts and houses: stone age and early metal age buildings in Finland. Finnish National Board of Antiquities, Helsinki, pp 53-64

Mökkönen T (2010) Kivikautinen maanviljely Suomessa. Suomen Museo 116:5-38

Mökkönen T (2011) Studies on Stone Age housepits in Fennoscandia (4000-2000 cal BC). Changes in ground plan, site location, and degree of sedentism. Unigrafia, Helsinki

Mökkönen T, Nordqvist K (2016) Quantifying Mineral Raw Materials in Neolithic Knapped Tool Production in the Lake Saimaa Area, Finnish Inland. In: ISKOS 21. New Sites, New Methods. Proceedings of the Finnish-Russian Archaeological Symposium. Helsinki, 19-21 November, 2014. Helsinki

Molinari C, Lehsten V, Bradshaw RHW, Powell MJ, Harmand P, Arneth A, Kaplan JO, Vannière B, Sykes MT (2013) Exploring potential drivers of European biomass burning over the Holocene: a data-model analysis. Glob Ecol Biogeogr $22: 1,248-1,260$

Moore PD, Webb JA, Collison ME (1991) Pollen analysis. Oxford University Press, Oxford

Nordqvist K, Herva V-P (2013) Copper use, cultural change and Neolithization in north-eastern Europe (c. 5500-1800 BC). Eur J Archaeol 16:401-432

Nordqvist K, Kriiska A (2015) Towards Neolithisation: The Mesolithic-Neolithic transition in the central area of the eastern part of the Baltic Sea. In: Kabaciński J, Hartz S, Raemaekers DCM, Terberger T (eds) The Dabki Site in Pomerania and the Neolithisation of the North European Lowlands (c. 5000-3000 cal $\mathrm{BC})$. Archaeology and History of the Baltic 8. Leidorf, Rahden/ Westf, pp 537-556

Nordqvist K, Mökkönen T (2016) New radiocarbon dates for early pottery in north-eastern Europe. In: Lozovskaya OV, Mazurkevich AN, Dolbunova EV (eds) Traditions and Innovations in the Study of Earliest Pottery: Materials of the international conference, May, 24-27, 2016, St. Petersburg, Russia. Russian Acedemy of Sciences, St. Petersburg, pp 204-214

Nordqvist K, Mökkönen T, Herva V-P (2014) Natural resources and Neolithic. Minerals and plants [Природные ресурсы и неолит. минералы и растения]. In: Mazurkekevich AN, Polkovnikova MZL, Dolbunova EV (eds) Archaeology of Lake Settlements of the 4th-2nd Millennia BC: Chronology of cultures, environment and palaeoclimatic rhythms. Materials of international conference dedicated the semi-centennial anniversary of the researches of lake dwellings in north-western Russia. Saint Petersburg, 13-15 November. The State Hermitage Museum, Russian Academy of Sciences. Herzen State University, Saint Petersburg, pp 202-207

Nordqvist K, Kriiska A, Gerasimov D (2015) Social'naâ reorganizaciâ naseleniâ kamennogo veka $\mathrm{v}$ vostočnoj časti Baltijskogo morâ v 4 tys. do n.e.: struktura rasseleniâ, strategiâ žizneobespečeniâ i sistema kommunikacij [Reorganisation of 
the Stone Age societies in the eastern part of the Baltic Sea in the 4th millennium BC: settlement structures, subsistence strategy and communication networks]. In: Čairkina NI (ed) IV severnyj arheologičeskij kongress: Doklady, Khanty-Mansiisk, October 19-23, 2015. Ekaterinburg, pp 132-152

Núñez M, Franzen P (2011) Implications of Baltic amber finds in northern Finland 4000-2000 BC. Archaeologia Lituana $12: 10-24$

Núñez M, Okkonen J (2005) Humanizing of north Ostrobothnian landscape during the 4th and 3rd millennia BC. J Nordic Archaeol Sci 15:25-38

Nurminen K (2007) Kalanluulöytöjä Suomen neoliittisilta asuinpaikoilta. Muinansitutkija 1/2007:2-17

Ojala AEK, Tiljander M (2003) Testing the fidelity of sediment chronology: comparison of varve and paleomagnetic results from Holocene lake sediments from central Finland. Quat Sci Rev 22:1,787-1,803

Olsson IU (1986) Radiometric dating. In: Berglund BE (ed) Handbook of Holocene Palaeoecology and Palaeohydrology. Wiley, Chichester, pp 273-312

Pesonen P (2002) Semisubterranean houses in Finland: a review. In: Ranta $\mathrm{H}$ (ed) Huts and houses: stone age and early metal age buildings in Finland. National Board of Antiquities, Helsinki, pp 9-41

Pesonen P, Oinonen M, Carpelan C, Onkamo P (2012) Early Subneolithic ceramic sequences in eastern Fennoscandia: a Bayesian approach. Radiocarbon 54:661-676

Piezonka H (2012) Stone Age hunter-gatherer ceramics of NorthEastern Europe: new insights into the dispersal of an essential innovation. Documenta Praehistorica 39:23-51

Piličiauskas G, Kisielienė D, Piličiauskienė G (2017) Deconstructing the concept of Subneolithic farming in the southeastern Baltic. Veget Hist Archaeobot 26:183-193. doi:10.1007/ s00334-016-0584-9

Pitkänen A, Huttunen P, Jungner H, Tolonen K (2002) A 10000 year local forest fire history in a dry heath forest site in eastern Finland, reconstructed from charcoal layer records of a small mire. Can J For Res 32:1,875-1,880

Poska A, Saarse L (2006) New evidence of possible crop introduction to North-Eastern Europe during the Stone Age. Cerealia pollen finds in connection with the Akali Neolithic settlement, East Estonia. Veget Hist Archaeobot 15:169-179

Poska A, Saarse L, Veski S (2004) Reflections of pre- and early-agrarian human impact in the pollen diagrams of Estonia. Palaeogeogr Palaeoclimatol Palaeoecol 209:37-50

Poska A, Meltsov V, Sugita S, Vasijev J (2011) Relative pollen productivity estimates of major anemophilous taxa and relevant source area of pollen in a cultural landscape of the Hemi_Boreal Forest Zone (Estonia). Rev Paleobot Palynol 167:30-39

Putkinen S, Saarelainen J (1998) Kullenbergin näytteenottimen uusi kevennetty malli [A lighter model of Kullenberg's sampler]. Geologi 50:22-23

Reille M (1992) Pollen et spores d'Europe et d'Afrique du nord. Laboratoire de Botanique Historique et Palynologie, Marseille

Reille M (1995) Pollen et spores d'Europe et d'Afrique du nord, Supplement 1. Laboratoire de Botanique Historique et Palynologie, Marseille

Reimer PJ, Baillie MGL, Bard E et al (2009) IntCal09 and Marine09 Radiocarbon Age Calibration Curves, 0-50,000 Years cal вP. Radiocarbon 51:1,111-1,150

Reynaud C, Hjelmroos M (1980) Myöhäiseltä mesoliittiselta ajalta lähtien siitepölyanalyysillä todistettu ja radiohiilimenetelmällä ajoitettu ihmisen vaikutus luontaiseen metsäkasvillisuuteen Pohjois-Pohjanmaan alueella. Faravid 4:41-75

Rimantienė R (1979) Šventoji. Narvos kulturos gyvenvietės. Vilnius, Mokslas
Rimantienè R (1999) Traces of Agricultural Activity in the Stone Age Settlement in Lithuania. In: Miller U, Hackens T, Lang V, Raukas A, Hicks S (eds) Environmental and Cultural History of the Eastern Baltic Region. PACT 57. Conseil de l'Europe, Rixensart, pp 275-290

Rimantienè R (2005) Die Steinzeitfischer an der Ostseelagune in Litauen. Litauisches Nationalmuseum, Vilnius

Rimkute V (2010) Chap. 35: The Neolithic Mats of the Eastern Baltic Littoral. In: Strand E, Andersson B (eds) North European Symposium for Archaeological Textiles 10. Oxbow Books, Oxford

Saarnisto M (1970) The late Weichselian and Flandrian history of the Saimaa Lake complex. Societas Scientiarium Fennica, Commentationes Physico-Mathematicae 37:1-107

Schweingruber FH (1990) Microscopic Wood Anatomy; Structural variability of stems and twigs in recent and subfossil woods from Central Europe, 3rd edn. Eidgenössische Forschungsanstalt WSL, Birmensdorf

Seitsonen O, Seitsonen S, Broderick LG, Gerasimov DV (2017) Burnt bones by Europe's largest lake: Zooarchaeology of the Stone Age and Early Metal period hunter-gatherers at Lake Ladoga, NW Russia. J Archaeol Sci Reports 11:131-146

Seppä H, Alenius T, Bradshaw RHW, Giesecke T, Heikkilä M, Muukkonen P (2009) Invasion of Norway spruce (Picea abies) and the rise of the boreal ecosystem in Fennoscandia. J Ecol 97:629-640

Sherratt A (1991) Sacred and profane substances: The ritual use of narcotics in later Neolithic Europe. In: Garwood P, Jennings D, Skeates R, Toms J (eds) Sacred and Profane. Oxford University Committee for Archaeology, Oxford, pp 50-64

Snowball I, Zillén L, Ojala A, Saarinen T, Sandgren P (2007) FENNOSTACK and FENNORPIS: Varve dated Holocene palaeomagnetic secular variation and relative palaeointensity stacks for Fennoscandia. Earth Planet Sci Lett 255:106-116

Stockmarr J (1971) Tablets with spores used in absolute pollen analysis. Pollen Spores 13:615-621

Sugita S (1994) Pollen representation of vegetation in quaternary sediments - theory and methods in patchy vegetation. J Ecol 82:881-897

Sugita S (1998) Modelling pollen representation of vegetation. In: Gaillard MJ, Berglund BE, Frenzel B, Huckriede U (eds) Quantification of land surfaces cleared of forests during the Holocene, vol 27: Palaeoclimate Research. Fischer, Stuttgart, pp 1-5

Sugita S, Parshall T, Calcote R, Walker K (2010) Testing the landscape reconstruction algorithm for spatially explicit reconstruction of vegetation in Northern Michigan and Wisconsin. Quat Res 74:289-300

Taavitsainen J-P (1982) A copper ring from Suovaara in Polvijärvi, Northern Karelia. Fennoscandia antiqua 1:41-49

Taavitsainen J-P, Simola H, Grönlund E (1998) Cultivation history beyond the periphery: early agriculture in the North European Boreal Forest. J World Prehist 12:199-253

Thompson R, Oldfield F (1986) Environmental magnetism. Allen and Unwin, London

Tinner W, Nielsen EH, Lotter AF (2007) Mesolithic agriculture in Switzerland? A critical review of the evidence. Quat Sci Rev 26:1,416-1,431

Tolonen M (1978) Palaeoecology of annually laminated sediments in Lake Ahvenainen, S. Finland. I: Pollen and charcoal analyses and their relation to human impact. Ann Bot Fenn 15:177-208

Tolonen M (1980) Postglacial Pollen Stratigraphy of Lake Lamminjärvi, S Finland. Ann Bot Fenn 17:15-25

Tolonen K, Ruuhijärvi R (1976) Standard pollen diagrams from the Salpausselkä region of Southern Finland. Ann Bot Fenn 13:155-196 
Tweddle JC, Edwards KJ, Fieller NRJ (2005) Multivariate statistical and other approaches for the separation of cereal from wild Poaceae pollen using a large Holocene dataset. Veget Hist Archaeobot 14:15-30

Ukkonen P (1996) Osteological analysis of the refuse fauna in the Lake Saimaa Area. In: Kirkinen T (ed) Environmental Studiesin Eastern Finland. Reports of the Ancient Lake Saimaa project, Helsinki Papers in Archaeology. University of Helsinki, Helsinki, pp 63-91

Vaneeckhout S (2009) Aggregation and polarization in northwest coastal Finland. Socio-ecological evolution between 6500 and 4000 cal BP. PhD Thesis, Department of Archaeology, University of Oulu

Vanhanen S, Pesonen P (2015) Wild plant gathering in Stone Age Finland. Quat Int 30:1-13

Vasks A, Kalnina L, Ritums R (1999) The introduction and pre-christian history of farming in Latvia. In: Miller U, Hackens T, Lang V, Raukas A, Hicks S (eds) Environmental and cultural history of the Eastern Baltic region. PACT 57. Conseil de L'Europe, Rixensart, pp 291-304

Vuorela I (1986) Palynological and historical evidence of slash-andburn cultivation in South Finland. In: Behre K-E (ed) Anthropogenic Indicators in Pollen Diagrams. Balkema, Rotterdam

Vuorela I (1999) The beginnings of agricultural land use in Finland: An assessment based on palynological data. In: Miller U, Hackens T, Lang V, Raukas A, Hicks S (eds) Environmental and cultural history of the Eastern Baltic region. PACT 57. Conseil de L'Europe, Rixensart, pp 339-351

Vuorela I, Lempiäinen T (1988) Archaeobotany of the site of the oldest cereal grain find in Finland. Ann Bot Fenn 25:33-45

Vuorela I, Saarnisto M, Lempiäinen T, Taavitsainen JP (2001) Stone Age to recent land-use history at Pegrema, northern Lake Onega, Russian Karelia. Veget Hist Archaeobot 10:121-138

Vuorinen J (1982) Piikivi ja Suomen kampakeraaminen piikauppa. Helsingin yliopiston arkeologian laitos, moniste n:o 30. Helsingin yliopisto, Helsinki
Vuorinen J (1984) Вуоринен, Ю. 1984. Торговля кремнем и янтарем в Финляндии в эпохи неолита In: Рыбаков БА (ed) Новое в археологии СССР и Финляндии. Наука, Ленинград, pp 54-60

Walanus A, Nalepka D (1999) POLPAL: Program for counting pollen grains, diagrams plotting and numerical analysis. Acta Paleobot 659-661. Suppl. 2

Werbart B (1998) Subneolithic: What it is? - Subneolithic societies and the conservative economies of the Circum-Baltic Region. In: Zvelebil M, Domańska L, Denenell R (eds) Harvesting the Sea, Farming the Forest. The Emergence of Neolithic Societies in the Baltic Region. Sheffield Archaeological Monographs 10. Sheffield Academic Press, Sheffield, pp 37-44

Wilson CA, Davidson DA, Cresser MS (2008) Multi-element soil analysis: an assessment of its potential as an aid to archaeological interpretation. J Archaeol Sci 35(2):412-424

Zagorska I (2006) Radiocarbon chronology of the Zvejnieki burials. In: Larsson L, Zagorska I (eds) Back to the Origin: New Research in the Mesolithic-Neolithic Zvejnieki Cemetery \& Environment, Northern Latvia. Acta Archaeologica Lundensia, Series in $8^{\circ} 52$. Almqvist \& Wiksell International, Stockholm, pp 91-113

Zagorska I (2008) The Use of Ochre in Stone Age Burials of the East Baltic. In: Fahlander F, Oestigaard E (eds) The Materiality of Death: bodies, burials, beliefs. BAR International Series 1768. Archaeopress, Oxford, pp 115-124

Zhul'nikov AM (1999) Eneolit Karelii. Petrozavodsk: Rossiyskaya akademiya nauk

Zhul'nikov AM (2003) Drevnie zhilishcha Karelii. Petrozavodsk: Skandinaviya

Zohary D, Hopf M, Weiss E (2013) Domestication of plants in the old world, 4th edn. Oxford University Press, Oxford

Zvelebil M, Lillie M (2000) Transition to agriculture in eastern Europe. In: Price TD (ed) Europe's first farmers. Cambridge University Press, Cambridge, pp 57-92 